\title{
8
}

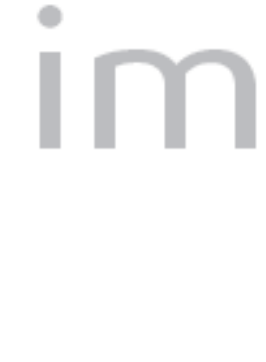

\section{prar IIIIm}

\section{Génio e individualização}

Autor(es): $\quad$ Pires, Edmundo Balsemão

Publicado por: Faculdade de Letras da Universidade de Coimbra, Instituto de Estudos Filosóficos

URL

persistente:

URI:http://hdl.handle.net/10316.2/29570

DOI:

DOI:http://dx.doi.org/10.14195/0872-0851_40_3

Accessed : $\quad$ 26-Apr-2023 11:20:58

A navegação consulta e descarregamento dos títulos inseridos nas Bibliotecas Digitais UC Digitalis, UC Pombalina e UC Impactum, pressupõem a aceitação plena e sem reservas dos Termos e Condições de Uso destas Bibliotecas Digitais, disponíveis em https://digitalis.uc.pt/pt-pt/termos.

Conforme exposto nos referidos Termos e Condições de Uso, o descarregamento de títulos de acesso restrito requer uma licença válida de autorização devendo o utilizador aceder ao(s) documento(s) a partir de um endereço de IP da instituição detentora da supramencionada licença.

Ao utilizador é apenas permitido o descarregamento para uso pessoal, pelo que o emprego do(s) título(s) descarregado(s) para outro fim, designadamente comercial, carece de autorização do respetivo autor ou editor da obra.

Na medida em que todas as obras da UC Digitalis se encontram protegidas pelo Código do Direito de Autor e Direitos Conexos e demais legislação aplicável, toda a cópia, parcial ou total, deste documento, nos casos em que é legalmente admitida, deverá conter ou fazer-se acompanhar por este aviso.

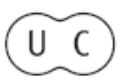




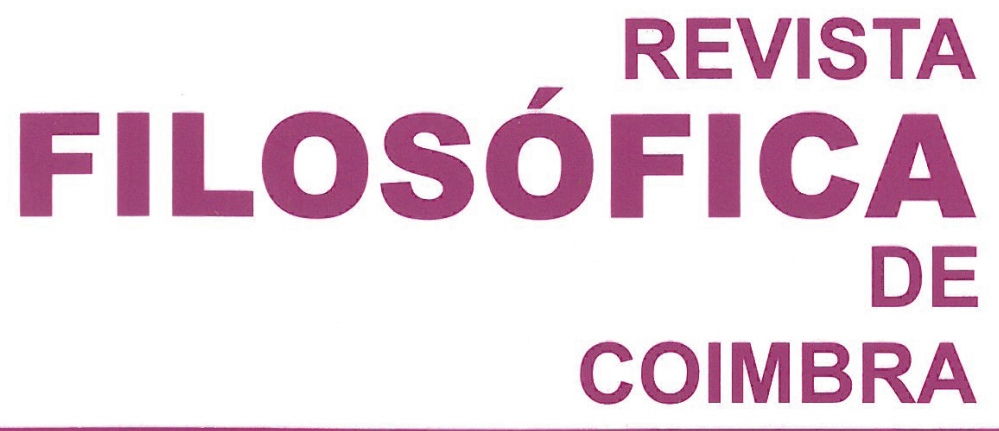

vol. 20 - número 40 - outubro 2011

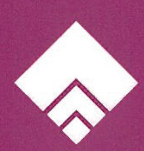




\title{
GÉNIO E INDIVIDUAÇÃO ${ }^{1}$
}

\author{
EDMUNDO BALSEMÃO PIRES*
}

\begin{abstract}
The present study deals with the genealogy of some terminological groups linked to the semantics of genius in modern Thought. Four major segments were isolated: melancholy, enthusiasm, taste and genius. The study seeks to show how the modern meaning of genius derives from the ancient depiction of the relation between melancholy and the "exceptional man" but profoundly alters the relation between Man and Nature. The distinction between melancholy and enthusiasm already shows that the terminology is not fixed in Antiquity. In modern society there are aspects of "enthusiasm" that will serve to describe what "melancholy" can no longer do. The modern themes of invention, originality or impetus reveal the special sensitivity of modern society towards novelty. The Eighteenth Century proposed for "genius" new meanings that are connected to the perception of novelty and at the same time to the need to preserve the coordination of psychological, biological and communicative dimensions of the "human nature". This double orientation characterizes Herder's essays. With Kant and his transcendental turn in Aesthetics the metaphysical foundations of "human nature" were criticized, thereby affecting the meaning and function of "genius".
\end{abstract}

Key words: genius, individuation, melancholy, enthusiasm, taste, Kant, Herder, Hegel.

Resumo: O presente estudo trata da genealogia de alguns grupos terminológicos ligados à semântica do génio no pensamento moderno. Isolaram-se quatro segmentos mais importantes: melancolia, entusiasmo, gosto e génio. $\mathrm{O}$ estudo procura mostrar como o sentido moderno do génio deriva do tratamento

${ }^{1} \mathrm{O}$ presente trabalho é um desenvolvimento parcial do tema de investigação "A Individuação da Sociedade Moderna".

* Departamento de Filosofia, Comunicação e Informação (FLUC). 
antigo da relação entre melancolia e "homem excepcional" mas altera profundamente o modo de entender a relação entre Homem e Natureza. A distinção entre melancolia e entusiasmo revela já como o termo não está fixado na Antiguidade e como na sociedade moderna há aspectos do "entusiasmo" que vão servir para designar o que a melancolia já não pode fazer. As notas modernas do génio em redor da invenção, originalidade ou ímpeto revelam a sensibilidade especial da sociedade moderna relativamente ao novo. O século XVIII propõe significados para o génio que estão ligados por um lado à percepção do novo e, ao mesmo tempo, à necessidade de manter a coordenação das dimensões psíquica, orgânica e comunicativa da "natureza humana". Esta dupla orientação caracteriza os ensaios de Herder. Com Kant e a sua viragem transcendental na Estética são os fundamentos metafísicos da "natureza humana" que se põem em causa afectando com isso o sentido e a função do génio.

Palavras chave: génio, individuação, melancolia, entusiasmo, gosto, Kant, Herder, Hegel.

\section{Abertura}

É possível rever na cultura do génio de 1800 uma elevada estima pela comunicação oral assim como a continuação da redescoberta das línguas e literaturas maternas. O próprio conceito de génio é um dos aspectos deste clima cultural de 1800 em transição para modelos mediáticos de comunicação e de comunicação literária, mais em particular que, de 1900 em diante, se irão afastar da ideia do autor literário como de um ser de excepção capaz de intuir o génio da língua e da pátria na singularidade da sua escrita. O génio literário não só descreve uma relação circular do indivíduo de excepção para consigo mesmo, uma vez que nada de exterior o pode explicar, mas ainda uma relação do indivíduo genial com a sociedade e com o meio de comunicação que exprime a relação social, ou seja, a língua. Na forma da relação auto-referente consigo mesmo, como um inexplicável ser de excepção ou ainda como indivíduo inefável, o génio apresentou-se como um herói da pátria e da língua.

Há aspectos desta figura do génio que se definem pelos modos como o indivíduo genial estabelece os seus nexos com o seu objecto. O génio exprime esta causalidade do objecto no sujeito como uma individuação do sujeito. Esta individuação adere a determinadas formas patológicas da experiência subjectiva e a uma relação com o tempo e a causalidade. $\mathrm{O}$ objecto causa o sujeito na modalidade da inspiração. O estar inspirado representa uma sujeição à causa-objecto mas de tal modo que esta última se confundiu já com o ser do sujeito. Na evolução do conceito e da sua semântica é notória 
a oscilação entre os pólos do génio melancólico e do génio entusiasta. Estes representam numa dada fase da evolução semântica formas distintas mas igualmente descrevem modos diferentes de conceber a relação entre o sujeito e a sua causa-objecto. No caso do melancólico o indivíduo genial aparece como efeito expressivo da sua causa, dominado e actuado por ela, preso a ela, no sentido de uma ausência de liberdade, enquanto o entusiasta reflecte a individualidade genial como fonte produtiva, ímpeto expansivo para fora de si. Em ambos os casos a referência do génio à sua razão de ser é interna e a fonte da inspiração é interna. A forma da relação com o tempo é, porém, distinta. Melancolia, entusiasmo (ou furor) e o chamado génio científico são três modalidades que não possuem a mesma forma de integração da individuação do sujeito, da causalidade e do tempo. As duas primeiras modalidades representam uma forma que liga o objecto e o sujeito individuado na interioridade da vida psíquica, das expressões orgânicas e da comunicação pela linguagem. $O$ referido génio científico traduz, ao contrário, uma tal fixação da objectividade que isso implica a clara exterioridade do objecto em relação ao sujeito de tal modo que a causalidade e o tempo surgem como condições extrínsecas ou modos da própria conexão objectiva, natural, dos acontecimentos. Aqui, a conexão do sujeito individuado com a verdade do seu objecto é reconhecida apenas no modo da condicionalidade natural em geral, segundo um nexo causal que é ele mesmo um nexo extrínseco. Não há lugar para o reconhecimento de uma unidade expressiva das dimensões orgânica, psíquica e comunicativa do génio, que é obrigatória no caso do melancólico ou do entusiasta. Na ciência, a relação externa que o sujeito mantém com a verdade do objecto levou Kant a rejeitar a ideia de um génio na ciência. Voltaremos aos seus argumentos.

De ponto de vista comunicativo, o génio define um nexo entre a forma subjectiva da auto-referência da individualidade bio-psíquica e a estimulação da comunicação produzida pela sua insinuação discursiva em contraste com os temas já aceites ou em contraste com as rotinas adquiridas. Génio é também um conceito histórico no sentido em que esta estimulação e irritabilidade é não apenas empiricamente variável, no sentido da situação empírica em que os discursos factualmente ocorrem, mas sobretudo porque a estimulação comunicativa muda consoante o horizonte histórico--semântico a que estão referidos a terminologia, os conceitos e os géneros discursivos em que o génio se situa.

Neste sentido, o génio representa uma forma de combinar elementos auto-referenciais de fontes diferenciadas (orgânica, psíquica e social) e um modo de exprimir a agregação e interpenetração dessas fontes na modalidade paradoxal de uma única referência. A nota da originalidade do génio tem no seu fundo os temas da novidade, do engenho e da surpresa. $\mathrm{Na}$ medida em que, como consequência da querela dos "antigos e modernos", 
a semântica identificadora do génio se associou ao novo, à invenção e à originalidade é a diferença entre tradição, norma e rotina por um lado e inovação, desvio e interrupção, por outro lado, que vem para o centro dos discursos. Mas há um conjunto de outras determinações semânticas que nos obrigam a seguir linhas de disseminação discursiva distintas como é o caso com o tema da inspiração.

A "querela dos antigos e modernos" também revelava na feição moderna do conceito de génio a complementaridade entre duas linhas semânticas mais significativas: uma que partia da novidade; a outra que se articulava a partir do tema da inspiração. A novidade e a inspiração podem considerar-se os dois temas maiores da cultura do génio do século XVIII e sob eles se distribuem diferentes ramificações semânticas que podemos reconstruir num quadrado que se organiza segundo os vértices da relação com o processo criativo, com a História, com a expressão da natureza pulsional do indivíduo e com a socialização. Deste modo, é-nos possível identificar com alguma clareza no eixo da relação entre novidade e História a distinção entre tradição e revolução ou tradição e reforma. No plano da compreensão do processo criativo ou no que concretamente se refere às descrições sobre a composição artística ou literária as distinções entre norma e desvio, rotina e interrupção são centrais. No tema da inspiração várias linhas de disseminação podem ser referidas. Mas, aqui, mais marcadamente se podem descrever dois grupos: um em que se insere a relação da inspiração com a natureza pulsional do sujeito; outro em que se articulam as tensões entre individualidade do génio, comunicação e comunidade de pertença.

Podem reter-se as diferentes linhas semânticas dos dois grupos maiores como resultado de esquemas de oposições binárias. O génio traduzse assim numa noção que é fruto de vários equilíbrios semânticos em vez de designar um conteúdo fixo. Para além disso, ao nos fixarmos na significação de cada um dos membros desses binários estaremos aptos a percorrer uma linha genealógica em que podemos situar noções adjacentes, textos fundadores para certos alinhamentos semânticos e toda a espécie de elementos e estratégias textuais reveladores de impasses, resistências, deformações ou inovações na significação. Uma História da semântica estará portanto alerta para as tensões nos processos discursivos e textuais de geração da significação dos termos e expressões.

Relativamente à forma da individuação a personalidade genial representa um exemplo claro de virtualização psíquica da observação social da evolução e, aqui, da representação da novidade. A sociedade moderna não pode separar-se do que, na verdade, é um dos traços que melhor a distingue de outras formas sociais, a saber: a sensibilidade ao novo e a incitação do novo. A partir do século XVIII o génio concretiza não só a atenção à 
novidade mas ainda a sua constituição como programa da subjectividade criadora. Há um conjunto de desvios semânticos importantes em relação ao conceito antigo que dão conta desta sensibilidade e deste programa. $\mathrm{O}$ facto de o génio se poder aplicar a uma multiplicidade de ocupações faz dele uma noção suficientemente abrangente para se acomodar também, convenientemente, a actividades diferentes da criação artística e literária. Na medida em que se diferencia do talento a relação entre génio e profissão ou entre génio e carreira é ambígua e geradora de controvérsia, de modo a poder assegurar, tanto quanto possível em exclusividade, a expressão da sensibilidade ao novo na modalidade de um tipo psíquico ou na forma de uma personalidade. Nisto, o génio desempenha tanto melhor a sua função social quanto maior for o seu valor diferencial frente às rotinas da reprodução social, em que se incluem as carreiras. A distinção entre génio e talento serve o propósito de uma remarcação da diferença entre o novo e o prolongamento, herança ou aperfeiçoamento do antigo.

Linhas semânticas essenciais da evolução do conceito no século XVIII revelam como mediante a referência à individualidade inspirada do criador de obras de arte se articularam respostas ao problema semântico e estrutural da relação entre as formas expressivas da consciência individual e as condições sociais do aparecimento do público moderno da arte. Estes dois aspectos resultaram de horizontes evolutivos que não possuem o mesmo ritmo nem os mesmos referentes, mas que se entrecruzam em diversos pontos. Aqui, a investigação da individuação pelo génio é uma análise dos pontos de engrenagem entre as formas modernas do público de arte e o gosto artístico, as definições e descrições do que é um criador, a descrição do processo da composição artística e a descrição da forma do juízo estético.

Temas como o gosto, o valor da imitação da natureza na criação artística e as narrativas (auto)-biográficas sobre a psicologia do génio e da inspiração ilustram pontos destas engrenagens. Mas nas Lições sobre Estética de Hegel aquelas articulações tomavam conta do centro da concepção filosófica da arte.

A sensibilidade ao novo é um traço distintivo da própria sociedade moderna. Graças a ela a sociedade observa-se a si mesma do ponto de vista evolutivo, em que a diferença em relação ao passado é constitutiva. Como se forma o novo pode tornar-se agora um problema e uma questão central com um componente psíquico e outro comunicativo.

Nas antecipações comunicativas da individualidade do génio exprime-se o modo como as formas da comunicação estruturam modelos de reconhecimento da individualidade, ou seja, modelos para reconhecer o desnível entre o que na comunicação é memória reprodutiva e antecipação rotineira das operações dos sistemas psíquicos e a contingência produtora de irritação, estimulação ou surpresa. O desnível em causa revela-se na 
arte, mas ainda em outros domínios em que se revê a diferença entre antecipação comunicativa sobre operações dos sistemas psíquicos ligada à memória reprodutora da comunicação e a dimensão factual da comunicação sobre sistemas psíquicos. O génio como individualidade de excepção ilustra como as possibilidades surpreendentes dos sistemas psíquicos se devem às próprias formas psíquicas de modulação do sentido mas também à sua diferença em relação ao expectável nos temas e tópicos disponíveis na comunicação. A distinção entre o esperado e a surpresa torna-se assim uma referência obrigatória no que concerne a uma definição do génio. Podemos mesmo dizer que o génio é esta distinção na forma da autoapreensão e como uma auto-referência da organização da vida psíquica. A inclusão na forma auto-referente da auto-biografia do génio da referência à relação entre antecipação comunicativa e dimensão factual das operações psíquicas é o que se significa como excesso da personalidade genial, como excentricidade ou fruto da fantasia ou ainda nas modalidades mais extremas como delírio, entusiasmo, possessão divina, etc. $\mathrm{O}$ génio como personalidade singular, como individualidade, é a auto-referência deste excesso e, consequentemente, a evidência do desnível. Vemos assim como a descrição da forma moderna do génio concebe a individualidade não como uma substância idêntica a si mesma segundo a sua essência, mas põe a tónica no valor distintivo e no carácter diferencial da auto-biografia genial como tensão, não resolvida, entre o expectável na comunicação e a novidade. O desnível entre o expectável e a surpresa não é só por si caracterizador do génio. Para incluirmos todas as dimensões deste último é ainda necessária a reflexão subjectiva e a sua conexão com as formas da comunicação, ou seja, a manifestação da auto-referência.

Se é possível relacionar a concepção moderna com a originalidade, a invenção e a novidade, já a ideia antiga do génio articula-a com a melancolia. Sabemos como Aristóteles dedicou atenção à presença do tipo melancólico nos homens dotados de génio ou a que se atribuíram actos ou pensamentos fora do comum. São dois grandes modelos da individuação, entre os quais se geraram diversos laços. Mas o tipo melancólico não pode servir já de figurino para o génio da modernidade. Veremos por que razão.

\section{Formas subjectivas do génio}

\subsection{O tema psicológico do carácter do génio}

Nos tratados de F. A. Carus e de C. Lombroso sobre a Psicologia do Génio revê-se o estado da consideração psicológica do tema no séc. XIX, 
no ponto de chegada temporal do presente estudo, em torno do carácter e do temperamento. Dois tópicos se podem isolar como determinantes, o da individualidade e o da excepcionalidade.

No capítulo sobre o génio da sua Psicologia F. A. Carus mostrava na fase crítica e de viragem da época do génio como sob este termo não se podiam agrupar os casos de comportamento psicológico pouco comum, os meros "originais" ou aqueles que aparentavam profundidade mas não a possuíam de facto, etc. Assim, depois de afastar um grupo de candidatos para definir o génio F. A. Carus mostrava como Kant tinha razão na sua definição de génio como o que "dita as regras da arte" e acrescentava a nota de uma força interior capaz de modelar os objectos pela capacidade criativa.

Mas, o que parece essencial para o nosso ponto de vista está no facto de F. A. Carus considerar que o génio é um indivíduo e só pode definirse mediante a auto-referência da individualidade. A tese de que só há um génio irrepetível pretende ilustrar precisamente esta ideia. Mas com ela o que o autor afirma é que individualidade e génio pertencem a um ciclo de definição e definidor que não é possível romper. O génio é definido como aquele que desde cedo assume e continua a sua própria individualidade, o que o identifica com um homem "original" 2 . Esta originalidade está associada a uma capacidade de se tomar a si mesmo como o que está sempre em causa no processo criativo. Não é a grandeza extensiva mas a relação e ponto de aplicação do talento que define o génio. Num grau menor ou maior todo o génio é Dichter, na medida em que ele põe a própria realidade criada a partir da sua força, talento e ponto individual de visão. Esta proximidade entre o génio individual e o poeta-criador fica ainda a dever-se ao facto de todo o génio implicar um elevado grau de imaginação livre que em virtude da ausência de impedimentos não se repete em outro eu.

Entre outras características como uma hábil faculdade de julgar, o espírito, a intensa energia psíquica, a aplicação da energia a actividades bem definidas, de modo duradouro, o gosto é uma faculdade definidora do génio e significa capacidade de escolha dos objectos estéticos em sociedade e ainda capacidade de orientar a sua faculdade de juízo estético segundo formas "sociais". O que representa a síntese máxima de todas as vertentes do génio é o espírito. O conceito de espírito exprime-se também mediante a categoria da individualidade e da individuação. De facto, este tratado de Psicologia afirma que no espírito a multiplicidade do indivíduo se exprime na máxima unidade. Esta unidade corresponde,

${ }^{2}$ F. A. Carus, Psychologie in Idem, Nachgelassene Werke, Erste Teil, Leipzig, 1808, p. 263. 
portanto, a um centro unificador de potências diferentes ${ }^{3}$. O que justifica esta unificação do múltiplo na individualidade genial, dotada de espírito, está em que o autêntico génio consiste na capacidade de mobilizar todas as faculdades e talentos na aplicação a um objecto durante toda a vida. Isto revela como a unidade de uma biografia é o que o génio consegue dominar e ao mesmo tempo exprimir. $\mathrm{O}$ que então concretiza o génio é a capacidade para formar essa unidade biográfica a partir de si mesmo, a partir da força de unificação do seu espírito. Não são apenas as obras exteriores que contam na definição mas sim a personalidade, na medida em que a constituição desta resulta de tal modo de um poder unificador que é a própria biografia que se pode conceber como produto do génio ${ }^{4}$. Este entra, por conseguinte, numa relação circular consigo mesmo. A circularidade do génio é outro modo de significar a sua individualidade e auto-referência.

A Psicologia do Génio é assim dotada de um objecto que é constituído pela unidade de sentido da organização autobiográfica da experiência de si e do mundo. No entanto, fica por elucidar até que ponto esta visão não exclui do tema o carácter excepcional do génio. A tradição mais antiga ia contra essa uniformidade e em quase todos os tópicos que lhe serviram para vincar a excepcionalidade encontrava-se o da loucura.

C. Lombroso escreveu uma obra famosa sobre o "Homem de Génio"5. Neste estudo o autor propunha-se investigar os nexos entre génio e loucura à luz de um esquema analítico utilizado anteriormente na investigação dos tipos criminais. A diferença em relação aos estudos anteriores prende-se com o facto de o autor afastar a identificação imediata entre génio e alienação. $\mathrm{O}$ que o preocupa é a análise do tipo de inteligência que vemos actuar no génio, que o diferencia do homem comum e que o aproxima de alguns traços da loucura. $\mathrm{Na}$ investigação deste tipo de inteligência será então necessário esclarecer que nexos mantém o génio com o talento, com a profundidade de espírito e outros traços de inteligência que o distinguem do homem vulgar. O que dele faz um indivíduo extraordinário não consistirá na sua originalidade? Uma possibilidade seria definir o génio frente ao meio-ambiente e mostrar como ele propõe visões originais da realidade que não estão presentes no mundo que o cerca. A invenção e a novidade caracterizam-no e distinguem a genialidade do talento. É esta distinção em relação ao tipo de inteligência esperado no comum dos homens que caracteriza a "anormalidade" do génio. Mas os loucos também possuem um modo inesperado e infrequente de associar

\footnotetext{
3 Idem, Ibid., p. 266.

${ }^{4}$ Idem, Ibid., p. 272.

${ }^{5}$ C. Lombroso, L' Homme de Génie, (trad.), Paris, 1889.
} 
as ideias. É fundamental, então, saber o que aproxima e o que distingue o louco do génio. Serão aspectos fisiológicos associados ao carácter? Existe um sentido de "anormal" que inclui o génio e a loucura e um outro que permite separá-los? Tem razão de ser a comparação do génio com uma "longa paciência"? Ou o génio é uma imoderação, um fruto espontâneo e dificilmente antecipável do exercício da inteligência sobre um assunto ou uma matéria? O carácter invulgar das associações de ideias dos maníacos, dos drogados e do homem de génio é a primeira coisa que salta à vista se comparamos estas formas de inteligência com a inteligência e os hábitos mentais do homem comum.

A tese de G. Lombroso afirma que ao contrário dos alienados o homem de génio combina a imaginação fluida e o espírito crítico muito agudo, o que faz com que não perca por completo o sentido de realidade.

A tese de uma patologia do génio está associada ao ponto de partida do autor na sua obra. Se aceitamos que a genialidade tem uma dimensão patológica, então é necessário descrever os seus sintomas e perceber se há o equivalente a uma semelhança de família neles. O criminologista recorda que foram Platão e Aristóteles que anteciparam na descrição da personalidade melancólica a ideia de uma patologia do génio. A inspiração é a ocasião da composição artística que permite do modo mais certo a comparação entre o louco e o génio.

O temperamento melancólico foi desde a medicina hipocrática associado ao génio e à loucura ${ }^{6}$. Depois da época de ouro da melancolia, a explicação dos aspectos mórbidos da personalidade genial foram objecto de investigação pelos "alienistas" do século XVIII e quase sempre os sintomas foram relacionados com a chamada "degenerescência". Para esta última foram encontradas algumas explicações etiológicas como a presença de doenças hereditárias ou o alcoolismo, a sífilis e outras doenças responsáveis por lesões cerebrais. A estas afecções de natureza "física" juntam-se os chamados indícios "morais" que se exprimem no comportamento dos indivíduos. Havia determinadas características físicas forçosamente presentes na caracterização externa do génio que iam desde a baixa estatura e mesmo o raquitismo, a uma grande ou diminuta massa encefálica até aspectos da fisionomia que só estão presentes em indivíduos retardados ou degenerados e que se podem rever também nos dementes. Do ponto de vista de dados biográficos a precocidade atribuída a muitos homens de génio deve considerar-se um atavismo e regista-se também entre os selvagens. A degeneração é um estado físico e psíquico que pode apresentar analogias no plano filogenético se tivermos em conta algumas características dos primitivos.

${ }^{6}$ Idem, Ibid., p. 3. 
Estes dois exemplos da Psicologia do século XIX, na fase de viragem e no período de cinzas da grande época do génio, motivam uma investigação detalhada da significação psíquica do génio para perceber essa persistente relação entre individualidade e excepcionalidade. Da enorme massa disponível para análise semântica optei por reunir dados textuais em torno de quatro núcleos que disponho em dois pares: melancolia e entusiasmo / gosto e génio.

\subsection{Melancolia e Entusiasmo}

As concepções da melancolia estão longe de ser uniformes de um ponto de vista histórico, semântico ou mesmo de enquadramento teórico ou científico. Do ponto de vista histórico o discurso teórico sobre a melancolia surgiu em relação com as ideias sobre os "quatro humores" que definiam para a ciência médica da Antiguidade as bases combinatórias dos fundamentos biológicos dos quatro tipos de carácter: o melancólico, o colérico, o fleumático e o sanguíneo segundo o predomínio da "bílis negra", da "bílis amarela", do fleuma ou do sangue. Na significação biológica e médica antiga na noção de humor e no conceito de disposições humorais (no sentido de potencialidade ou faculdade, dynamis) contêm-se descrições do comportamento e do estado de espírito subjectivos do homem. O Homem é considerado como espécie natural e na medida em que os humores e as disposições que delas provêm têm o seu suporte material numa determinada combinação dos elementos que também compõem o mundo é inevitável a relação com o cosmos e com as combinações objectivas dos quatro elementos que ultrapassam o microcosmos limitado do Homem e do Animal. No livro Saturno e a Melancolia ${ }^{7}$ R. Klibansky, E. Panofsky e F. Saxl mostraram os elos da evolução do modelo cosmo-antropológico das doutrinas humorais e da melancolia desde os pitagóricas passando por Empédocles e a sua escola médica na Sicília até Aristóteles para concluir que as ideias mais antigas sobre o tema combinaram teses da medicina empírica sobre os humores e certos fluídos corporais com ideias sobre proporção, ritmo biológico e cósmico (as estações do ano e as estações da vida) e isonomia numa perspectiva geral da saúde. A distinção entre saúde e doença deve-se ao equilíbrio ou desequilíbrio periódicos da circulação e composição humoral no organismo.

As teorias sobre os quatro humores acabam por evoluir para doutrinas sobre carácter e temperamento do indivíduo moldadas segundo as caracte-

\footnotetext{
${ }^{7}$ R. Klibansky, E. Panofsky, F. Saxl, Saturne et la Mélancolie. Études Historiques et Philosophiques: Nature, Religion, Médicine er Art (trad.), Paris, 1989.
} 
rísticas dos humores (os "quatro temperamentos") e ainda no sentido de descrições nosológicas que tomam por base cada um dos humores. O humor melancólico foi tomado como o responsável principal pelo desequilíbrio do estado saudável e pela doença, sobretudo quando havia sintomas no estado mental dos doentes, como desorientação grave, abatimento profundo, misantropia, fobias e certos tipos de delírio. O tipo melancólico situou-se, portanto, ao mesmo tempo, num quadro caracterológico dos temperamentos e também no quadro nosológico, considerando-se como um estado patológico ou como uma forte disposição para a doença. Neste último caso, a melancolia é uma doença do espírito.

As descrições histórico-filosóficas puseram-nos perante a dificuldade de estabelecer um nexo entre esta tradição médica, as ideias platónicas do Fedro sobre o entusiasmo e as teses atribuídas a Aristóteles no texto do Problema $X X X^{8}$ em que o estagirita alegadamente considerava o temperamento melancólico como o tipo mais próximo dos homens de excepção ou do génio. O Problema XXX parece articular a tese repetida vários séculos depois de que a melancolia, um determinado balanço de bílis negra no organismo, é a marca do génio. De facto, o texto começa por constatar que o excesso de bílis negra é encontrado em vários tipos de homens excepcionais como filósofos, políticos, poetas, artistas e ainda nos heróis. Ele explica, também, comportamentos atribuídos ao "mal sagrado". A comparação com os homens ébrios serve ao autor para explicar que os estados e acções do melancólico provêm dele mesmo, da sua natureza, e não são acidentais ou provocadas por causas externas. Aqui está um elemento chave: o que define o melancólico ou o génio não se pode explicar com recurso a uma epigénese, mas é endogénico. Vemos como na tradição antiga em que se situa o Problema $X X X$ esta auto-referência do génio se definiu como uma "natureza". A natureza e a natureza do melancólico, em particular, é uma dynamis, o que significa que consiste em um poder que está sempre entre a latência e a actualidade. Certos traços do carácter-tipo do melancólico podem não estar presentes nos casos particulares. Isto disfarça os sintomas e pode tornar difícil a distinção entre o consumidor de vinho, ou seja o melancólico ocasional, e o que, por natureza, tem propensão para apresentar aqueles estados e comportamentos. Para identificar um melancólico temos, então, de descobrir o seu temperamento, que é expressão da sua natureza. Na discussão do tema da natureza vemos como o autor acede ao conceito de humor e composição humoral que atravessa as dimensões orgânica e psíquica. Quanto ao seu temperamento, a composição orgânica de um indivíduo depende da mistura dos quatro humores que têm como base física os quatro elementos e as

\footnotetext{
${ }^{8}$ Sigo a tradução a partir de R. Klibansky em Idem, Ibid., pp. 51-75.
} 
diferenças do quente-frio e seco-húmido. Mas entre os humores é à bílis negra que se deve uma influência evidente nos estados da consciência. No caso da bílis negra o seu arrefecimento conduz a estados depressivos e a medos e o aquecimento à euforia, à dança, ao canto, a êxtases e a actos audazes. O autor do Problema $X X X$ equaciona assim os dois pólos do quadro do temperamento maníaco-depressivo seguindo a dynamis de um humor orgânico determinado. Os homens excepcionais resultam de um grau determinado de calor e frio na sua bílis negra que os torna capazes de criar e de agir, segundo a sua anormalidade relativa, e os distingue da condição de monstros, de indivíduos apáticos ou demasiado agitados. Quando refere o pólo eufórico da bílis aquecida o autor chama-lhe entusiasmo colocando esta condição psíquica dentro da melancolia, ao contrário da solução dada por Platão no Fedro.

Em tese, os autores de Saturno e a Melancolia consideraram que este desvio em relação a Platão representou da parte de Aristóteles uma fuga ao mito e à crença associada a um transporte divino do entusiasta e uma redução do génio a condições naturais ${ }^{9}$. Mas não deixa de ter consequências relativamente ao lugar dos dois conceitos um em relação ao outro, pois Platão não subordinou o entusiasmo à melancolia.

Ainda no mundo antigo, em redor do temperamento melancólico e da sua expressão no génio estavam lançadas as bases para várias vias de investigação, como a que se relacionou com a Poética e as teses sobre a inspiração dos artistas (Platão no Íon, no Fedro e na República e Aristóteles na Poética); com a Política e a descrição do temperamento dos tiranos e dos reis (Platão e Aristóteles no Problema XXX); a Medicina com o desenvolvimento das teorias humorais na sua aplicação aos casos patológicos da melancolia e à loucura (os tratados hipocráticos, Rufus de Efeso e Galeno); a reflexão moral que vai incidir sobre o valor ético das perturbações melancólicas (os estóicos) e as várias aproximações que se podem ler em todas estas fontes entre melancolia, exaltação religiosa e profecia, que se retomarão na modernidade no debate sobre o entusiasmo. A equivalência que Cícero estabeleceu entre os termos gregos "mania" e "melancolia" e o latino "furor" (Tusculanae Disputationes III, V) acompanharam depois a semântica da melancolia, mesmo no caso dos escritos médicos que associaram a melancolia a estados de exaltação seguidos de febre, tristeza e abatimento. É no entanto impossível ignorar na maior parte destas investigações uma preocupação central com a individualidade no homem e com as suas causas orgânicas e psíquicas. Esta reconhece-se no nascimento da Fisiognomonia como uma disciplina voltada para a individualidade como expressão, orgânica e psíquica, situada

${ }^{9}$ Idem, Ibid., p. 89. 
entre a semiologia médica antiga das doenças psico-somáticas e o estudo das características singulares do homem saudável que se pode rever nos Caracteres de Teofrasto.

A Idade Média vai receber as discussões morais e as doutrinas médicas antigas sobre a bílis negra no quadro dos problemas teológicos das doutrinas do pecado, da queda e da salvação, em que tem o seu lugar o tratamento das pessoas afligidas por delírios, êxtases (incluindo os sobrenaturais), manias, profunda tristeza ou "acedia", vistos como fenómenos da possessão demoníaca. Não me posso dedicar aqui à exploração desta literatura medieval, mas no que se refere ao seu núcleo teórico essencial nota-se a persistência da teoria dos quatro humores e dos quatro temperamentos, de proveniência hipocrática e aristotélica, e a tendência para localizar a melancolia patológica no cérebro ${ }^{10}$.

No contexto do Renascimento neo-platónico M. Ficino escreveu os três livros sobre a Vida como um tratado de orientação existencial e sobre a saúde dos sábios onde se mostra uma combinação original das doutrinas humorais antigas, de astrologia e de concepções psicológicas e éticas. Nesta combinação tem um lugar especial o conceito de espírito, ora usado no singular ou no plural, para caracterizar o nexo entre corpo e alma. Em vários capítulos $\mathrm{M}$. Ficino discorre sobre a melancolia, sobre o seu lugar ao lado dos outros humores, sobre a influência na inteligência e na actividade intelectual, sobre a sua relação com a conjugação astral, nomeadamente com as posições de Saturno, sobre a má e a boa melancolia.

No livro I, caps. 3, 4 e 5 do De Vita Triplici ${ }^{11}$ M. Ficino explica por que razão os estudiosos e filósofos são melancólicos ou se tornam tal e retoma o tópico da perturbação do juízo sob influência da bílis negra desproporcionada. No cap. 5 reforça a identificação entre temperamento melancólico e génio, explicitamente com base no Problema XXX.

Identificou M. Ficino três diferentes causas do temperamento melancólico dos estudiosos, a saber; a causa celeste, a natural e a humana. A identificação das duas últimas faz-se em parte pela retomada das doutrinas humorais, mas a clarificação da primeira é uma especulação mágica sobre a influência de Mercúrio e Saturno. Saturno é o planeta responsável pela conservação da actividade da consciência por contribuir alegadamente para um certo repouso na actividade do espírito, o equivalente a uma contracção e concentração. A explicação da causa natural também não obedece a observação empírica mas ao contrário parte da suposição de que o saber começa de fora para dentro e da periferia da alma para o seu centro interior. Ora, no cosmos, o correspondente ao centro é a própria terra

\footnotetext{
${ }^{10}$ Idem, Ibid., p. 163-164.

${ }^{11}$ M. Ficino, Liber de Vita in tres libros divisus / Buch vom Leben in drei Teilbüchern (trad. alemã R. Hirth), 2007: pascua.de/ficinus.
} 
(o centro da terra) que é constituída pela mesma substância da melancolia. Esta última deve ser a responsável por aquilo que, no Homem, atrai para o centro, que é essencial no saber e na vida do sábio. Assim se concebe uma correspondência geral entre o celeste e o terreno que não se baseia apenas nos elementos naturais constitutivos da terra e dos outros planetas, mas nas próprias forças actuantes, que são idênticas em todo o cosmos. Entre o macro- e o microcosmos a analogia não é apenas simbólica no que se aplica aos elementos e humores mas também no que se refere aos ímpetos. A bílis negra exprime a força contractiva máxima do universo que na sua inscrição humana coincide com a contemplação e com o poder de concentração do sábio contemplativo (I, IV, 8). Recuperando a tradição platónica e neo-platónica sobre a Alma do Mundo e o biós theoretikós aristotélico M. Ficino fixa o sentido da contemplação numa ascensão ou elevação à região mais alta que, no Homem, implica quase uma separação ou desligamento de alma e corpo até alcançar no cosmos o planeta mais alto, Saturno na tópica coeva. No Homem, esta elevação e desligamento resultam da poderosa contracção que a melancolia assegura segundo a sua inscrição cerebral. Sendo uma elevada contracção do espírito e da alma individual do pensador, a contemplação realiza no mundo terreno, no Homem, o que só tem coincidência no ponto mais alto do cosmos.

$\mathrm{Na}$ literatura médica até ao século XVIII vamos encontrar tratados e ensaios dedicados às causas e formas de tratamento da melancolia como um mal psico-somático sem uma ligação evidente ao tema do génio, mas em que continuará presente o quadro geral da doutrina dos humores e das suas combinações pelo seco e húmido ou quente e frio. Estes textos não evitam o problema da relação alma-corpo, que aliás está no centro e justifica várias recomendações terapêuticas. A higiene e a dietética são duas dimensões da terapia. Na sua prescrição, os autores têm em conta os princípios ontológico e mágico da semelhança, da contrariedade e da mistura, da atracção, da repulsa e da composição, de origem pré-socrática mas de grande importância em Platão e em Aristóteles. Em redor da utilização de certas plantas, como a helébora negra, se pode rever a tripla orientação da medicação nos campos da medicação vomitiva, purgativa e geral baseada na ideia da analogia entre o "interior" e o "exterior", a alma e o corpo ou a natureza, a terra, os minerais, vegetais e animais e o homem. Se estas noções médicas podem dizer pouco sobre a relação entre melancolia e génio, elas informam-nos detalhadamente sobre o uso da analogia simbólica como forma de conceber o nexo entre o microcosmos e o macrocosmos. No A Treatise of Melancholie $(1586)^{12}$, um detalhado

12 T. Bright, A Treatise of Melancholie. Containing the causes thereof with the phisicke cure, and spirituall consolation, London, 1586. 
tratado médico-filosófico sobre a melancolia escrito para consolar um amigo com os sintomas desse mal, Timothy Bright partia do conceito antigo dos humores para conceber sob "melancolia" o desarranjo causado por um excesso ou defeito na composição quente ou fria da bílis negra num organismo, que é causa do lançamento de vapores prejudiciais no cérebro. Ao localizar a bílis negra no sangue trata-a simultaneamente como um componente normal e como um excremento que deve ser expelido quando a sua proporção relativamente aos demais humores não é a certa. A sua taxa no organismo varia consoante a alimentação e a assimilação orgânica dos alimentos que provêm em última análise da terra, que passa nos vegetais sob forma mineral e nos animais sob forma mineral e vegetal. A proporção dos elementos na mistura corpórea é algo de individual, o que justifica que a terapia tenha em conta o caso como irrepetível e singular. Para mostrar a influência dos elementos corpóreos na alma o autor recorre à concepção do Renascimento e de M. Ficino relativa a um nexo entre alma e corpo no espírito, que alegadamente corria no sangue e se ia afixar no cérebro, como algo de muito subtil e fluído. Afirma que a melancolia afecta sobretudo o cérebro e o coração do homem, pois nestes dois órgãos se revelam as diversas afecções do juízo, do raciocínio e das emoções que se manifestam nos que padecem deste desequilíbrio. Reflecte-se bem na concepção deste tratado o que significa espírito. À luz da combinação entre a perspectiva instrumental e a do ímpeto o tratadista mostra como o espírito, comparado a uma mão da alma a agir dentro do corpo, não conhece partes embora se distribua por elas e é muito célere, representa o núcleo da actividade orgânica ${ }^{13}$ pois é por ele que o impulso da alma se liga às diferentes partes do corpo, divisível e lento, gerando movimentos e sensações, como sua força interna, garantindo a distribuição proporcional da vida em cada domínio segundo a mesma proporcionalidade geométrica da justiça, a partir de diferentes centros vitais como o coração, o fígado e o cérebro ${ }^{14}$. Pela referência ao ímpeto anímico os movimentos e estases são aspectos obrigatórios da análise da composição humoral do organismo e com base nestas duas variáveis vai ser possível também integrar as emoções, como o amor e o ódio, a alegria e a tristeza, no quadro dos quatro temperamentos. Mas a teoria instrumental do corpo e a ideia da soberania orgânica da alma coloca o problema de saber se a perturbação melancólica começa na alma e no espírito ou na composição corpórea propriamente dita. De acordo com o nosso tratadista as alterações dos humores têm o maior impacto no cérebro seguido do coração e daqui espalham-se pelo resto do corpo. Como a velocidade da

\footnotetext{
${ }^{13}$ Idem, Ibid., p. 61 e ss.

14 Idem, Ibid.,p. 64.
} 
comunicação entre o cérebro e o coração depende de cargas humorais no sangue variáveis quanto à proporção dos quatro humores, densidade e subtileza, calor e frio, secura e humidade, uma sobrecarga ou abaixamento dos níveis humorais normais pode causar perturbações, gerar um espírito confuso e as emoções correspondentes. Dos quatro humores a bílis negra é a que parece apresentar uma maior variedade de localizações orgânicas no cérebro, baço, veias, coração, útero e estômago ${ }^{15}$. A sua desproporção em relação aos outros humores causa uma aparência externa concordante com a sua composição que é espessa, terrestre e escura ${ }^{16}$. A desproporção da sua composição no organismo e o tipo de vapores que produz no cérebro faz com que os pacientes tendam à circunspecção no juízo e raciocínio. A sua cor escura exprime uma têmpera pesada, triste e abatida que explica os constantes medos e pavores.

O tema da maior ou menor agilidade do espírito está presente também na discussão da Psicologia do génio como um critério de comparação entre o homem normal e o de "excepção", tentando mostrar-se como a agilidade da imaginação na comparação das ideias e das impressões, na retenção e na rememoração e na combinação inventiva de ideias é a marca do génio.

Vários tratados ou relatórios médicos se seguiram ao de $\mathrm{T}$. Bright sobre a melancolia ou sobre casos de pacientes melancólicos, com pressupostos antropológicos semelhantes, no século XVI mas sobretudo no século seguinte. Entretanto, a distinção entre "melancolia natural", como representativa de uma taxa equilibrada de bílis negra orgânica, e a "melancolia mórbida", como signo de um excesso, estabelecia-se no séc. XVII, ao lado da diferença entre a "melancolia mórbida" e a melancolia dos homens excepcionais. Em 1597 de André du Laurens foi publicado um Discurso sobre as Doenças Melancólicas e os Meios de as Curar ${ }^{17} \mathrm{com}$ referências teológicas sobre a origem da alma e a excelência do Homem. Partindo das doutrinas humorais antigas e dos Problemas de Aristóteles o autor distingue entre vários tipos de melancolia consoante as combinações da bílis negra, entre as quais conta a melancolia dos homens excepcionais, a que chama "hommes ingenieux"18, desenvolve a sua síntese sobre as principais faculdades do espírito (imaginação, memória e razão) e submete especialmente a escrutínio a imaginação, nomeadamente no que se refere à proximidade e diferença entre a imaginação e o "sentido comum" ou

15 Idem, Ibid., p. 98.

${ }^{16}$ Idem, Ibid., p. 125.

17 A. Du Laurens, Discours de la Conservation de la Veue, des Maladies Mélancholiques, des Catarrhes, et de la Vieillesse, Paris, 1597.

18 Idem,, Ibid., pp. 114-115. 
interno e à distinção entre a imaginação nos animais e no Homem. As ideias do autor sobre a imaginação vão no sentido da prova do carácter simultaneamente prático e contemplativo da imaginação humana e para a demonstração da sua independência do "sentido comum" dos escolásticos. Por este exemplo vemos como a imaginação se começa a centrar no horizonte da investigação da melancolia até ocupar, mais tarde, o lugar pneumatológico do espírito. A melancolia é novamente concebida como uma afecção cerebral mas segundo várias formas. Du Laurens não identifica o melancólico doente com o génio, a que também chama "melancólico são". Sobre a formação dos estados mentais dos "homens de engenho" diz-nos que resultam de uma combinação muito singular de humores, cujos vapores no cérebro fortalecem o corpo, melhoram o desempenho da memória e tornam profunda a imaginação. O produto final é um "santo furor" ${ }^{19}$ a que se dá o nome de entusiasmo. Assim se começa a consolidar, no interior da semântica médico-filosófica da melancolia, a associação entre imaginação poderosa, génio e entusiasmo, o que é decisivo para as alterações de sentido que iremos percorrer.

Em 1621 publicava-se a primeira edição da enciclopédica e influente Anatomia da Melancolia de R. Burton ${ }^{20}$, que aqui é impossível analisar com detalhe. Vou limitar-me a uma síntese drástica da parte I. Um dos primeiros tópicos recuperados nesta obra é o da excelência da espécie humana na criação e o carácter entristecedor da doença em alguns dos seus indivíduos, tema decalcado de T. Bright. Para além deste lemos ainda o tópico da relação microcosmos - macrocosmos, que inclui a alma e o corpo humanos, e que a obra vai recuperar da tradição clássica neoplatónica, uma vez mais à luz de uma concepção da expressão que, no que concerne à relação alma-corpo, se exemplifica no dito the body is domicilium animae ${ }^{21}$. No que se refere aos alicerces orgânicos, a obra de R. Burton representa um avanço na sistematização da localização anatómica dos humores e dos espíritos. O espírito no singular fica reservado a um medium peculiar, o "mais subtil vapor", que corre no sangue e é o instrumento da alma para desempenhar no corpo as suas actividades. É também entendido como o mediador entre corpo e alma ${ }^{22}$. Dele saem os espíritos que percorrem o organismo. Os humores repartem-se nos quatro tipos mas o tratado introduz alguns subtipos. A mesma sistematização se pode encontrar no tratamento da Psicologia e nas divisões da alma e das

${ }^{19}$ Idem, Ibid., p. 116.

${ }^{20}$ R. Burton, Democritus Junior, The Anatomy of Melancoly, Oxford, 1638, the fifth edition corrected and augmented by the author.

${ }^{21}$ Idem, Ibid., p. 173.

22 Idem, Ibid., p. 15. 
faculdades. No que se refere à imaginação, o autor distingue-a do "sentido comum" 23 e confere-lhe uma actividade reprodutiva e produtiva. Na parte I, secção I, o autor definia a doença e as doenças do cérebro. Seguidamente, estabelecia uma tipologia das doenças mentais e incluía a melancolia nas doenças resultantes de afecções da imaginação e da razão.

Nas doenças mentais, a loucura (Madness) é mais intensa e violenta que a melancolia. Mas em ambas estamos perante sintomas próximos como é o caso das "fúrias" que se subdividem nos tipos dos êxtases, entusiasmos, revelações ou visões, possessões demoníacas, profecias e "fúrias poéticas" 24 . Os melancólicos usam abundantemente a imaginação e é do seu abuso que resultam as fantasias arbitrárias que os afligem e que também se verificam no caso dos poetas e pintores. O tratado faz remontar a Galeno a tese de que a imaginação tem a maior responsabilidade na melancolia ${ }^{25}$ para de seguida temperar essa ideia e dizer que a fantasia acaba por corromper a própria razão e a faculdade de julgar, ou entendimento (parte I, secção 2, subsecção 2). Na parte I, secção 2, subsecção $15 \mathrm{R}$. Burton trata do estudo e das musas como causa da melancolia e o autor que toma como referência principal, sobretudo na explicação astral da contemplação, é M. Ficino. Com base no conceito de contemplação de M. Ficino, na equivalência entre o mais contraído na alma e o mais elevado no universo, as suas digressões referem-se aos estudiosos, aos académicos, que considera estarem expostos mais facilmente à melancolia em virtude do estudo prolongado e de um consequente desequilíbrio na relação entre alma e corpo. O seu desprendimento do corpo, da riqueza, do exercício ou da dieta torna-os frequentemente pobres ou miseráveis e servis e a sua miséria é tanto maior quanto mais elevado o objecto do estudo e, nesse estado, são seduzidos pelas musas.

Tomando a dado ponto como um exemplo o quadro de A. Dürer Melencolia I o exame mais completo do estado de espírito melancólico está na parte 1 , secção 3 , subsecção 2 a propósito dos variados e mesmo contraditórios sintomas psíquicos da melancolia orgânica como o taedium vitae, o descuido de si, as aflições constantes, os medos, o descontentamento, suspeições, inveja, as queixas, paixões violentas e abatimento, uma intensa e generalizada instabilidade.

As duas divisões finais do tratado remetem para as categorias da melancolia amorosa e melancolia religiosa em que os sintomas se podem rever mas agregados a outras manifestações como os êxtases. A categoria religiosa é investigada como um tipo de "entusiasmo".

\footnotetext{
23 Idem, Ibid., p. 23.

${ }^{24}$ Idem, Ibid., p. 9.

${ }^{25}$ Idem, Ibid., p. 32.
} 
Do exame dos vários textos sobre a melancolia deste elenco limitado é-nos possível concluir que a grande maioria dos temas conexos são o fruto de uma efabulação. A melancolia da tradição clássica até ao séc. XVIII é uma fábula que parte do enigma do equilíbrio (desequilíbrio) na relação entre corpo e mente e tenta dar-lhe uma resposta. Vemos claramente como na fábula da melancolia e do génio melancólico está presente a diferença e a descontinuidade entre processos psíquicos e processos da causalidade orgânica e como a melancolia revela essa diferença ao mesmo tempo que a mascara à luz do conceito de uma expressão recíproca do orgânico no psíquico e vice-versa.

Na passagem à semântica do génio do século XVIII a carga sémica do génio melancólico é naturalmente conservada, mas sofre uma alteração importante. Esta última deve procurar-se, em parte, na noção de entusiasmo. A carreira desta noção far-se-á a partir do filão neo-platónico do furor divino, teo-psíquico-orgânico, mas com evidentes desvios no sentido de uma categoria psíquico-orgânica para se tornar, por fim, num significado psíquico-social.

No século XVII, o primeiro tratado sistemático sobre o entusiasmo é o de Méric Casaubon, A Treatise concerning Enthusiasme, de $1655^{26}$. Trata-se de uma obra atenta aos acontecimentos religiosos de um período conturbado da História Inglesa em que abundam os exemplos de Entusiasmo Religioso ou "Melancolia Religiosa". No Tratado encontramos uma divisão dos tipos de entusiasmo no "divinatório", "contemplativo, teórico ou filosófico", no "retórico", no "poético" e no "entusiasmo da prece religiosa" ou da pregação. Estas divisões sobrepõem-se ou integram as distinções do mesmo objecto na concepção platónica do entusiasmo do Fedro e as divisões de Plutarco nos tipos divinatório, coribântico, poético, marcial e erótico ${ }^{27}$. O autor partia da etimologia do termo para mostrar que o "entusiasmo" supõe uma participação em poderes divinos, possessão ou plenitude divina na alma humana. Mostra ainda que no uso do termo se manteve sempre desde a Antiguidade a alusão à doença, especialmente nas referências cruzadas à melancolia que não deixam depois de surgir em todas as observações modernas que associam o entusiasmo a estados maníacos. A melancolia e o entusiasmo estão directamente referenciados nas formas antigas da arte divinatória, mas também nos comportamentos dos adeptos das seitas religiosas e em movimentos messiânicos do século XVII. A diferença entre um entusiasmo sobrenatural e outro natural pode envolver dificuldades terminológicas se em tese se aceita que o entusiasmo

${ }^{26}$ Méric Casaubon, A Treatise concerning Enthusiasme as it is an effect of Nature, London, 1655.

${ }^{27}$ Idem, Ibid., p. 13. 
se define, em geral, pela possessão divina. Mas o tratadista segue esta distinção para enquadrar o seu objecto de estudo, que será apenas o tipo do "entusiasmo natural", e afirma que as formas naturais de entusiasmo são todas aquelas que se podem explicar por causas naturais e não por um poder efectivo do diabo ou de uma divindade. Outros termos para designar o entusiasmo natural são "fervor" ou "ardor" que ele considera os nomes latinos mais aptos para verter o termo grego. Como entre as causas naturais se podem contar as doenças uma parte da explicação do entusiasmo natural passa pela medicina e pelo diagnóstico de padecimentos como a melancolia ou a epilepsia ${ }^{28}$. Os melancólicos e os epilépticos revelam estados de êxtase em que dizem coisas ou "falam línguas", cujo sentido não é habitual, cantam, agitam-se ou tremem, predizem o futuro ou têm os mais diversos tipos de visões, incluindo a visão de Deus. No caso de alguns melancólicos em que a diferença entre uma melancolia produzida pelo corpo e a "melancolia da alma", adquirida pelo estudo, pela teoria ou pela devoção religiosa é difícil de determinar, sendo os mesmos sintomas exteriores os que se traduzem no "êxtase melancólico"29 os seus estados entusiásticos são igualmente de uma origem imprecisa e a única coisa evidente é o tal ardor imaginativo e a profusão de imagens.

Todos os tipos de entusiasmo estão associados a um uso privilegiado da imaginação e o entusiasmo é um exagero da fantasia na representação da realidade interior que modifica as disposições dos homens para acreditar e para agir, tal como se estivessem possuídos por forças superiores. Para M. Casaubon o recurso político-teológico ao entusiasmo está documentado nas formas religiosas mais recuadas e manifesta sempre o recurso à fantasia exaltada. O que se conhece da inspiração religiosa desde a remota Antiguidade, das revelações divinas e das profecias tem a marca do entusiasmo. $\mathrm{Na}$ modalidade do entusiasmo teórico ou contemplativo é possível encontrar traços de entusiasmo nos filósofos antigos, como Platão, e ainda nos poetas $^{30}$. Mas para o autor o importante está em mostrar como nos vários tipos de entusiasmo as perturbações residem na faculdade imaginativa que podem contaminar o entendimento ${ }^{31}$. Uma parte considerável das observações do autor vai para a discussão do problema de saber como é que a imaginação pode causar alterações tão profundas da percepção e ser de tal modo influente nas acções dos indivíduos e no discurso.

No capítulo sobre o "Entusiasmo Poético" encontram-se várias considerações sobre como a imaginação febril se desenvolve no discurso,

\footnotetext{
28 Idem, Ibid., pp. 65-66.

29 Idem, Ibid., p. 102.

30 Idem, Ibid., p. 8.

31 Idem, Ibid., p. 88-89.
} 
por meio da inspiração poética. Para fixar o tipo particular do entusiasmo poético pela presença da inspiração, o tratado recorre a Aristóteles e a autores coevos.

Inicialmente publicado em 1656, o Enthusiasmus Triumphatus, or a Brief Discourse of the Nature, Causes, Kinds, and Cure of Enthusiasm ${ }^{32}$, do homem de religião Henry More, é usualmente apontado como um caso de retórica contra o "entusiasmo", nomeadamente contra o uso religioso do "entusiasmo" ou furor. Trata-se de um escrito polémico que tem como objectivo principal a rejeição de um fundamento transcendente na Graça Divina da inspiração religiosa das seitas que dominaram a vida religiosa de 1500 originando convulsões políticas tão graves quanto a revolta anabaptista de Münster de 1535. São várias as seitas próximas de correntes anabaptistas que mantiveram a sua actividade nesta altura, mas H. More parece sobretudo concentrado nos Quakers e nos grupos ditos "familistas", inspirados em adeptos de David George, o profeta, que ganhavam novo fôlego em 1650 e que se baseavam no entusiasmo, nos êxtases, e no fervor como revelações de Espírito Santo e provas de eleição profética.

Na quarta edição de uma "Colecção de vários Escritos Filosóficos do Dr. Henry More", publicada em 1712, o Breve Discurso aparecia a seguir a um Antídoto contra o Ateísmo em que o autor pretendia rejeitar os argumentos dos ateus e propor uma cura contra o que descrevia como uma doença da razão e do entendimento. O Breve Discurso sobre o Entusiasmo retoma o tom e parte dos temas do Antídoto e propõe-se mostrar como tanto o ateísmo como o entusiasmo religioso são frutos do mesmo tipo de perturbação da mente, cuja fonte é a fantasia ou imaginação exacerbada e um desequilíbrio no uso da razão. As duas perturbações são complementares, pois uma inverte o que a outra é. Mas as duas acabam por se justificar mutuamente no seu combate. A raiz dos dois padecimentos reside na melancolia destemperada e nos seus efeitos nocivos na imaginação.

$\mathrm{O}$ autor considera que a imaginação pode produzir imagens com um grau de intensidade determinada a ponto de se tornar convincente para $\mathrm{o}$ espírito. É nestas circunstâncias que os visionários, nos êxtases, declaram ter tido conversas com anjos ou encontros com o diabo quando não se passou outra coisa a não ser um sonho acordado. Os fanáticos encontram-se neste número de pessoas afligidas por uma imaginação que as leva para além delas mesmas quando por exemplo se apresentam como o Messias. $\mathrm{O}$ autor toma várias vezes como alvo correntes messiânicas e proféticas que anunciavam com evidente fervor o fim dos tempos e o caso particu-

${ }^{32}$ H. More, Enthusiasmus Triumphatus, or a Brief Discourse of the Nature, Causes, Kinds, and Cure of Enthusiasm in Idem, A Collection of several Philosophical Writings of Dr. Henry More, London, 1712. 
lar das profecias e do messianismo de David George (secções XXXIV e XXXV) que, devido à defesa de uma comunidade das mulheres, ele julga tratar-se de um caso de temperamento sanguíneo misturado com entusiasmo.

A sua investigação sobre o entusiasmo e o ateísmo leva-o a considerar praticamente apenas causas psíquico-somáticas na génese destas tendências. Daí deriva a grande importância que vai ter o temperamento melancólico para o Breve Discurso. É na melancolia, como "a compleição mais religiosa que há", que H. More vai encontrar a inclinação para acreditar ou descrer vivamente de alguma coisa. Ora, para ele, isto significa que é a constituição natural dos indivíduos que os leva a ter esta ou aquela representação fantástica e a crença associada e não a graça divina. A melancolia quente acompanha habitualmente os estados de intenso fervor e zelo em matéria religiosa enquanto a melancolia fria está presente nos actos de mortificação ou na extrema humildade perante o divino. O mesmo argumento no sentido da redução do entusiasmo aos estados melancólicos se aplica ao caso especial dos estremecimentos dos Quakers considerados pelo autor como "a mais melancólica das seitas" na secção XXV do Breve Discurso.

No capítulo XIX do Essay concerning Human Understanding ${ }^{33}$ J. Locke dedicava-se à exposição crítica do "entusiasmo". O entusiasmo encontra-se ao lado de duas outras forças do espírito humano que o levam a aderir a determinadas premissas como verdadeiras. As outras duas forças são a razão e a fé. $O \S 6$ definia entusiasmo segundo a descrição interna dos próprios "entusiastas" como uma iluminação directa de Deus influindo no curso da imaginação e produzindo um impulso no sentido de agir em concordância com a vontade de Deus. J. Locke considera que aqui não se trata nem do entendimento nem de revelação divina propriamente dita mas sim de um imperativo vindo de dentro dos próprios indivíduos no sentido de eles agirem em conformidade com os impulsos vindos deles mesmos (§ 7). O facto de estes indivíduos serem de algum modo passivos em relação aos seus próprios impulsos justifica, segundo ele, que se tenha em conta no entusiasmo o papel dos estados melancólicos e da devoção. Tratando-se de uma inspiração o estado de espírito dos entusiastas leva-os a praticar as mais estranhas acções. Pela sua adesão à iluminação imediata o entusiasta é sempre levado a uma "certeza sem prova e sem exame" e considera-se sempre acima do entendimento comum na justificação dos seus impulsos mais estranhos e incompreensíveis, pois diz-se sempre movido por Deus.

33 J. Locke, An essay concerning human understanding, with Thoughts on the conduct of the Understanding in three volumes, vol. III, Edinburgh, 1801, pp. 198-208. 
Tendo por modelos Teofrasto e La Bruyère, a obra Charateristics de Shaftesbury ajudou a consolidar no século XVIII um tipo particular de "moral", que não tem qualquer relação com uma preceptiva ou com uma ética no sentido de uma orientação para a "vida boa", mas representa uma moral na acepção do "mores" latino, implicando um observador da realidade dos "costumes", dos "modos", das "atitudes" e "cerimónias" que estão presentes numa sociedade e se concretizam em tipos psicológicos. O observador da "ciência dos costumes" está aqui anunciado, mas com este também se insinua uma figura muito distinta do génio melancólico e do entusiasta na relação com a moral. De acordo com os estudos de R. Horlacher ${ }^{34}$ para o caso alemão, esta "moralistica" assumiu neste país uma coloração pedagógica forte associada com modelos e projectos educativos.

$\mathrm{Na}$ sua Carta sobre o Entusiasmo, que nos ocupa neste ponto, Shaftesbury parte nas suas reflexões do hábito de os poetas se referirem no início dos seus textos às musas inspiradoras ${ }^{35}$. A questão que coloca é a de saber se há uma suficiente familiaridade com o mundo antigo para justificar o uso de uma referência tão abundante às musas entre os escritores modernos actuais. Trata-se de uma autêntica crença ou de uma fé fingida? Depois de algumas considerações sobre a imitação dos antigos que leva os poetas modernos a usar a mesma referência às musas que os seus antecessores, Shaftesbury concentra-se no enunciado da tese de que a verdade é muito poderosa, pois a fantasia e a imaginação têm forçosamente de gerar uma semelhança com ela para poderem produzir no público ou nos leitores algum impacto nas paixões da alma. A semelhança com a verdade nos trabalhos da fantasia é a verosimilhança. A verosimilhança de uma representação que afecta a alma do sujeito é a causa de determinado tipo de resposta ao objecto representado e este último não se dissocia da auto-afecção. Assim, a verosimilhança gera as condições de adesão da acção do sujeito à face cognitiva da representação e à sua face emocional, a esta última segundo o modo da auto-afecção. A auto-afecção e a capacidade de ter presente o modo como o sujeito se relaciona com as diversas fontes das paixões da alma é igualmente o ponto de partida para uma "medida" das coisas, ou faculdade de julgar, que o autor considera entre os dois limites do "ridículo" e do "sério".

A crença na presença das musas excita suficientemente as paixões da alma para acender o génio ${ }^{36}$. Por outro lado, a Carta refere-se à excitação de certas paixões internas devido à presença de um nexo social com

${ }^{34}$ R. Horlacher, Bildungstheorie vor der Bildungstheorie: die Shaftesbury-Rezeption in Deutschland und der Schweiz im 18. Jahrhundert, Würzburg, 2004, p. 26.

35 Shaftesbury, A Letter concerning Enthusiasm, London, 1708, p. 6.

${ }^{36}$ Idem, Ibid., p. 11. 
outrem que pode motivar a excitação do génio pessoal. Na ausência de um vínculo com outrem, como amigos ou apoiantes de uma causa comum, podem não ser despertas as paixões da alma necessárias para a eloquência de um orador. Este aspecto, que provém da doutrina do ethos do orador da Retórica de Aristóteles, evolui nos escritos dos contemporâneos da Carta para concepções sobre a natureza do "sentido moral" que liga os homens em sociedade e vai ser indispensável para a modificação do sentido psicológico inicial do entusiasmo.

There is a melancholy which accompanys all enthusiasm ${ }^{37}$. Com esta referência a uma afirmação contida no Breve Discurso de H. More, Shaftesbury estende a concepção dos humores às nações e povos, no sentido de mostrar equivalentes colectivos dos comportamentos individuais e das paixões individuais. Em certas passagens da Carta o entusiasmo é praticamente identificado com uma emoção colectiva, com um contágio ou "simpatia" que é bem visível no pânico mas também em determinadas reacções colectivas que o autor associa à religião. Nestas circunstâncias, o furor está presente nos comportamentos e o aspecto das multidões assemelha-se a um estado infeccioso tal como o descrito nas teorias humorais. A relação social por simpatia é a causa da corrente única que liga a multiplicidade dos estados de espírito dos indivíduos de tal modo que se deve dizer a respeito da grande variedade de experiências de contágio do entusiasmo que se está perante variedades do pânico. Mais ainda, o entusiasmo pode originar um comportamento infeccioso grave em que os indivíduos perdem a noção das regras.

O remédio que é recomendado contra o seu excesso é o "bom humor"38. O mau humor é a fonte do ateísmo ou das ideias segundo as quais o mundo é governado por uma poderosa força maligna. Ao contrário, o "bom humor" é fonte de uma verdadeira e piedosa religião, pois sossega as aflições. O espírito entusiasta em religião acaba por ser semelhante ao melancólico, pois nos dois casos há uma deficiência de bom humor e de boas maneiras no tratamento das coisas da fé. O modo melancólico de relacionamento dos homens com a religião impede o bom humor em matéria de fé. Só o bom humor permite rever o lado bom de Deus em matéria religiosa. A expansão infecciosa do entusiasmo, por delírio mimético, para além de afectar a relação social é ainda responsável por uma destruição completa do funcionamento normal dos sentidos e da imaginação, de tal modo que em vez de tornar o homem apto para apreender a realidade e de tornar possível um adequado conhecimento de si contribui para fazer crescer a inspiração como uma febre. Este estado febril e extático é comparado por Shaftesbury à profecia.

\footnotetext{
${ }^{37}$ Idem, Ibid., p. 21.

38 Idem, Ibid., p. 35.
} 
Na composição poética o entusiasmo participa como mola de inspiração: No poet (...) can do anything great in His own way, without the imagination or supposition of a divine presence, which may raise him to some degree of this passion we are speaking of ${ }^{39}$.

A definição de inspiração parece ser aqui extremamente simples e refere "um sentimento real da presença divina" 40 . O termo "fanatismo" aplica-se então apropriadamente e designa uma aparição que ilumina e que transporta a mente para além dela de uma forma anormal.

O artigo "Enthousiasme" na Encyclopédie (1765) de Diderot e d'Alembert é já uma consequência da Carta de Shaftesbury e dos vários escritos contra os excessos de "entusiasmo" na religião, que não podiam deixar de fora o exame do conceito na sua totalidade, incluindo o aspecto do entusiasmo poético. É um texto notável e permite-nos clarificar algumas mutações semânticas na conjugação de "entusiasmo", "génio", "razão" e "imaginação". Em nota do artigo seguinte com o título "Enthousiaste" estabelece-se a demarcação entre a "pessoa dada ao entusiasmo" e o "fanático". O "entusiasta" é a designação preferida para o sujeito do entusiasmo nas "belas-artes". O "fanático" representa um entusiasta em outro sentido, fora do âmbito das "belas-artes" e ainda segundo uma acepção negativa. A entrada "Enthousiastes" clarifica um pouco mais os significados do entusiasmo fora das "belas-artes" ao assinalar que com aquele termo se referem indivíduos supostamente agitados pelo demónio ou então certos adeptos de seitas religiosas como os Anabaptistas ou os Quakers.

No artigo "Génie" a Encyclopédie alinhava na identificação semântica da época entre a força sensitiva e criadora do génio e o entusiasmo, mas partia do pressuposto do isolamento semântico entre entusiasmo e fanatismo.

O artigo sobre o "Entusiasmo" parte do uso comum do termo que remete para um "furor que acomete o espírito, que incendeia a imaginação e a torna fecunda" e, como um transporte, leva a actos extraordinários. O texto sublinha o "furor" como indício do entusiasmo. Mas isso serve para identificar a possível oposição entre a razão e a aparente loucura que está latente no furor entusiástico. Com efeito, as coisas extraordinárias que os entusiastas fazem parecem ditadas por um delírio irracional muito próximo da loucura. O autor afasta esta oposição para mostrar como é no conceito de génio que a razão e o furor do entusiasmo se unem sem contradição. Contrariamente à conexão habitual entre entusiasmo e imaginação o autor do artigo considera que o génio se deve sobrepor à imaginação e deve mesmo considerar-se "génio" o acto que põe a imaginação em

\footnotetext{
${ }^{39}$ Idem, Ibid., p. 79.

${ }^{40}$ Idem, Ibid., p. 81.
} 
movimento. O exemplo da composição pictórica que o autor dá não é por acaso: ele contrapõe um quadro pintado com base exclusiva na memória reprodutiva ao acto de pintar do génio, que compõe algo de completamente novo, que não pode ser dominado pela memória e que impera inexplicavelmente no movimento do pincel ao longo da tela, levando a mão. O domínio da tela pelo génio é, todavia, um domínio racional que não se explica apenas pela imaginação.

Por outro lado, segundo um outro aspecto, o artigo da Encyclopédie é decisivo para a nossa exposição. Segundo ele, o entusiasmo tem como outra característica a comunicabilidade e a sua rápida expansão e contágio. Isto justifica-se, especialmente no caso da arte, na relação íntima entre criação e público como uma relação de "entusiasmos", de uma ligação entre os espíritos analogada a um "fogo mútuo".

Ora, se comparamos na mesma Encyclopédie o art. "Entusiasmo" com o art. "Melancolia" vemos como os dois termos não são já aproximáveis nem conceptualmente nem na significação geral, o que é sintomático da viragem entretanto operada no que do conceito de génio os modernos retiveram. $\mathrm{O}$ conceito de entusiasmo serve agora para designar o que no génio é ímpeto, invenção e força original, mas também capacidade de contágio social, comunicabilidade. O génio melancólico maníaco-depressivo, na sua dualidade de espírito deprimido e exaltado, tornava-se já pouco interessante para salientar a exaltação colectiva que o novo génio anunciava a um mundo que se parecia cada vez mais consigo e que, de certo modo, o havia mesmo antecipado.

\subsection{Gosto e génio}

Para o início da época do génio as polémicas que opuseram "antigos" e "modernos" têm sem dúvida uma grande importância, na medida em que fixaram os ensaios de definição do génio em redor da oposição maior entre imitação e invenção. Ao eixo opositivo imitação - invenção se agregou um conjunto de ideias gerais sobre o gosto e sobre a evolução dos "modos" e "costumes" da vida em sociedade. Boileau serviu de exemplo aos defensores da imitação e da imitação da natureza, mais particularmente. Também foi ele que reforçou várias associações semânticas como por exemplo a que liga génio, espírito e gosto.

Mas a noção de génio está marcada essencialmente pela nota da excepcionalidade. É esta última que permite revelar a estreita ligação entre a personalidade dotada de uma inteligência anormal no modo como estabelece a associação de ideias e a individualidade. Os traços semânticos agregados ao furor, à força inexplicável e ao carácter não habitual 
da inteligência do génio são aspectos de uma concepção da inspiração que já não está limitada à orla semântica que opõe imitação e invenção. A ideia de que o génio é a "alma da alma", o "espírito do espírito" prepara uma explicação do carácter inventivo segundo a qual a originalidade é resultado de uma subjectividade que não pode deixar de ser fora do normal em virtude da força irresistível que a anima interiormente. É esta agregação da semântica do furor à da invenção a responsável pela criação do conceito romântico do génio. A relação entre a invenção e o furor marca o começo de esquemas interpretativos novos para a sociedade referir a novidade, que se exprimem na ideia de génio. Ambas as noções se passam a agregar às notas que o pensamento clássico atribuía ao génio e ao seu carácter singular e inefável.

No séc. XVIII o tema do gosto estava muito difundido nas discussões sobre literatura e sobre costumes e gozava de grande poder de modulação semântica em associação com outros temas e termos como o da moda, do luxo, os próprios "costumes", o "progresso", o "polimento", a influência do comércio na vida dos povos e a "cultura", o "público" e o génio artístico e literário num sentido geral. Estamos no século da "crítica", que nasce e se desenvolve como um género literário dedicado à apreciação da literatura com o seu tipo particular de observação do que se passa não tanto na realidade social, política ou nos "costumes" mas no seu reflexo escrito e na relação com o público. A crítica assume um papel tão central para a vida literária que Voltaire no Temple du Goût (1733) escreve que tous les Honnêtes-gens qui pensent, son critiques ${ }^{41}$.

Sendo o interesse pelo gosto um sinal da importância entretanto adquirida pela crítica, é de assinalar que disso resultou sobretudo a instabilidade da significação, das "regras", dos modelos literários e uma crise generalizada do ideal da imitação servil. Tudo isto se exemplifica bem, com humor, na fortuna do poema de Voltaire sobre o Templo do Gosto.

A diferença entre o homem rude e o civilizado atravessa análises teóricas e ensaios literários que vão desde a teoria económica sobre a sociedade civil, às concepções sobre o valor do comércio nas nações até esboços de Filosofia da História em que a relação entre progresso, polimento e gosto está presente. A distinção entre natureza e sociedade embebe de dificuldades a discussão sobre o que é o bom ou o mau gosto e vemos que, em escritores como Montesquieu, a diferença entre o "gosto natural" e o "gosto adquirido" se tornou focal abrindo-se por aí, também, o tema da delicadeza dos costumes e da oposição entre o selvagem e o civilizado. Para além de tudo o mais que se possa dizer, o interessante neste

${ }^{41}$ Voltaire, Le Temple du Goût. Édition Véritable donnée par l'Auteur, Amsterdam, 1733, p. ix. 
clima literário está no facto de nele se envolverem problemas filosóficos relativos à influência da sociedade e da situação social na capacidade de sentir e, em especial, na faculdade de sentir prazer ou de ajuizar sobre o que é agradável ou não. É um tema que está no limiar entre a organização psíquica das faculdades e a comunicação em sociedade. Nas discussões do séc. XVIII sobre o gosto, o sentimento do prazer e do agradável a socialização do gosto está presente, mesmo que isso não ocorra de um modo consciente e explícito. O exercício ensaístico mais claro nesta direcção, por parte de um artista, é o de Allan Ramsay no seu A Dialogue on Taste dos finais da década de $1750^{42}$.

Saído em Amesterdão em 1736, de François Cartaud de la Villate chegou-nos um Essai Historique et Philosophique sur le Goust ${ }^{43}$ em que o autor narra o processo de socialização do Homem através da História, desde as épocas recuadas em que os homens viviam mais próximos da natureza. Em parte, trata-se de uma descrição da História Humana como um desenvolvimento dos costumes de certos povos, como os gregos, os egípcios, os romanos que conheceram a adaptação das suas formas de sentir ao meio-ambiente físico-geográfico e às instituições políticas e religiosas. $\mathrm{O}$ autor refere-se a diferenças na forma de sentir e de obter prazer entre os diferentes povos e, não obstante o seu estilo impressionista, tenta descrever a influência das formas de vida social e do comércio nos sentimentos, nas artes, na eloquência e na religião. O gosto, a delicadeza, o polimento ou os ímpetos selvagens ou bárbaros são uma expressão final deste conjunto de factores a que têm ainda de se juntar as considerações de tipo fisiológico, que este autor não deixa de ter em conta ao referir os humores, por exemplo, o maior ou menor peso da melancolia no carácter.

O Ensaio sobre o Gosto $(1757,1783)$ de Montesquieu e a Dissertação sobre o Gosto para servir de introdução ao Inquérito sobre a origem do Belo e do Sublime (1757) de E. Burke são dois casos de discussão do tema que mais uma vez revelam a dupla condição parasitária das condições sociais relativamente aos processos fisio-psicológicos e vice-versa.

O Ensaio de Montesquieu começa com uma descrição do prazer e dos seus três tipos para seguidamente revelar nas três fontes do prazer os três objectos do gosto: há prazeres que se tiram do fundo da própria alma; prazeres que resultam da união da alma com o corpo; finalmente, há prazeres que dependem da vida institucional e da relação com os outros. Nestas divisões nos apercebemos da tripla fonte da dificuldade de uma teoria do gosto e da sua unificação duvidosa.

42 Allan Ramsay, A dialogue on taste, London, 1762 (the second edition).

${ }^{43}$ F. Cartaud de la Villate, Essai Historique et Philosophique sur le Goust, Amesterdam, 1736. 
Outras expressões relacionadas com experiências a que se aplica o prazer são o belo, o agradável ou o sublime, que se articulam naquelas três fontes do prazer. Como essas expressões traduzem o prazer de um modo diferente à luz do tipo de experiências em causa tem de haver alguma faculdade no sentido de determinar o seu bom uso nos diferentes casos e para permitir ajuizar sobre ajustamentos ou desajustamentos. Ora, é esta faculdade a que Montesquieu chama gosto: a faculdade de descobrir com finura e prontidão a medida do prazer que cada coisa deve dar aos homens ${ }^{44}$.

Impõe-se, contudo, uma precisão na determinação dos prazeres da alma que ligamos ao sentimento do gosto. É a precisão que deriva da diferença entre o gosto natural e o gosto adquirido.

A constituição psíquico-orgânica do Homem está nos fundamentos da faculdade de sentir e é, por isso, uma base do gosto. A máquina psíquico-orgânica garante um certo alcance sensorial às faculdades e uma certa profundida à capacidade para sentir. Se a nossa constituição humana conhecesse alterações, então as diferentes artes também sofreriam com isso e possivelmente não nos dariam as satisfações anteriores. As artes estão obrigatoriamente dependentes da constituição psíquico-orgânica do Homem para proporcionar os seus efeitos. O gosto natural é uma aplicação das nossas faculdades sobre certos objectos com base na estrutura psíquico-orgânica com que nascemos.

Não conhecemos as regras que presidiram à relação entre as faculdades do Homem e o prazer que se retira da relação com os objectos naturais ou com as obras de arte. É por isso que o gosto natural é sempre indeterminado.

A relação entre o gosto natural e o que chama "gosto adquirido" é uma relação de expansão que começa na base psíquico-orgânica mas que se modifica pelo sentimento interno. A importância do sentimento de si, da auto-afecção, na transformação da base psíquico-orgânica inicial do gosto é o que leva o autor a considerar fundamental a orientação do gosto para o espírito. Este último altera de modo mais ou menos completo o gosto natural. $\mathrm{O}$ espírito é o género do qual dependem as espécies do bom-senso, do discernimento, da justiça, do talento, do gosto e do génio. Pelo espírito o gosto natural adapta-se à vida social e transforma-se por sua mediação. É desta modificação do equipamento psíquico-orgânico com que se nasce que resulta a outra definição de génio do Ensaio e que diz que o gosto é o "prazer delicado dos homens do mundo" 45 . Como é

${ }^{44}$ Montesquieu, Essai sur le Goût in Idem, Euvres Complètes, Paris, 1964, pp. 845-852, p. 845.

45 Idem, Ibid., p. 846. 
evidente, trata-se de uma tentativa de síntese entre a condição inicial do processo sensorial na relação alma-corpo com as formas da comunicação em sociedade. Esta síntese opera no lado psíquico-orgânico do sentimento assim como na sua face social. $\mathrm{O}$ índice da actuação do espírito na base inicial do gosto natural reside na curiosidade. A curiosidade é sinal de que o espírito actua movendo a atenção, deslocando-a de um foco inicial de ideias e não permanece fechado nas ideias já conhecidas, leva da simplicidade à multiplicidade, do todo ao detalhe e deste novamente àquele. A curiosidade é a razão de ser do gosto adquirido e refinado e a sua ausência é prova de estreiteza. Uma atenção lenta é o equivalente a uma impossibilidade de captação das partes do conjunto nesse conjunto de uma forma económica para o sistema psíquico e quanto mais ágil é o espírito no movimento das partes para o todo mais ele revela o génio, o gosto apurado e o sentido das proporções.

Daqui se segue a relação entre as diferentes modalidades de conceber a relação partes-todo, a curiosidade e os prazeres respectivos como o prazer da simetria, o prazer dos contrastes, os prazeres da surpresa, a delicadeza, graciosidade ou o belo por oposição. Sobre a relação entre arte, gosto adquirido e regras a conclusão do Ensaio pode parecer surpreendente. A tese de Montesquieu subordina a arte ao gosto e a composição artística à influência do gosto, mas sem regras pré-definidas. A arte, para ser arte de bom gosto, não pode subordinar-se integralmente a regras. Mas só o gosto pode indicar em que circunstâncias a arte se deve afastar das regras ${ }^{46}$. Lembremos que entre as teses mais influentes da época estão as doutrinas que sustentam que o gosto é o conhecimento das regras que se podem aplicar à arte para esta reproduzir a proporção natural e, por conseguinte, não só subordinam a arte às regras como o gosto ao conhecimento das regras.

As ideias de E. Burke sobre o gosto da Dissertação sobre o Gosto reflectem a distinção entre o gosto natural e o gosto adquirido, mas as conclusões que daqui se retiram são diferentes das de Montesquieu. A tese geral diz-nos que o gosto é igual em todos os homens do ponto de vista da sua base sensorial. Mas na medida em que ele se transforma pela imaginação é-lhe necessário saber se a imaginação consegue alterar tão profundamente a informação sensorial que cria coisas "novas". A Dissertação traz para o centro a relação entre o novo, o gosto e a imaginação, o que implica associar representações da corrente de consciência, representações psíquicas, portanto, com representações do tempo público e que, por conseguinte, implicam a sociedade. Para ele, é decisivo saber se a imaginação é uma faculdade da variação da sensação ou mais que

\footnotetext{
${ }^{46}$ Idem, Ibid.,p. 851.
} 
isso. Sendo uma faculdade da variação sensível seria reprodutiva, dotada de passividade. Mas o autor afirma que a imaginação é um terreno muito extenso em que ocorrem variações da consciência em torno da percepção interna do prazer e da dor assim como em redor das paixões. Ora, disto ele conclui que o que influi nas paixões vindo dos sentidos é igual em todos os homens e que a imaginação é somente responsável pela representação do que se dá nos sentidos: o que afectou os sentidos afecta da mesma forma a imaginação e esta só compara e distingue entre o que já foi fornecido e experimentado sensorialmente. $\mathrm{O}$ gosto não difere quando apreende na sensação as qualidades de algo ou quando reproduz pela imaginação os primeiros conteúdos da experiência sensorial. $\mathrm{O}$ que se chama "mau gosto" não é afinal outra coisa a não ser uma certa falta de atenção dirigida para o objecto primitivo da sensação ou para a regra da sua imitação artística. A boa regra é aquela que permite à imaginação reproduzir a exacta proporção do objecto sensorial e daqui construir a obra de arte reproduzindo o objecto. Esta regra é o gosto. Pelo gosto os homens conseguem gerar ideias acertadas sobre as imitações da natureza, segundo o processo sensorial, e conseguem distinguir entre a imitação verdadeira e a imitação falsa nos juízos resultantes. Assim, o gosto, subordinando-se à verdade, regula a identidade do objecto sensorial e do objecto imaginário. A causa do mau gosto está numa deficiente formação do juízo. Quando a atenção para o objecto é bem dirigida e o processo criativo obedece às proporções naturais do objecto o resultado só pode ser a concórdia dos homens na sua apreciação estética segundo o sentimento do agradável. A imitação pode ser falha em certos aspectos e isso conduzir a uma imaginação artística defeituosa e a uma obra defeituosa. Mas quando se dá o acordo sensorial, imaginativo e da obra de arte tudo o que daí decorre é o juízo verdadeiro, em que a humanidade concorda.

Destes pressupostos retira E. Burke uma consequência da maior importância. As paixões que se acendem de cada vez que é proposto um novo objecto da imitação aos sentidos e à imaginação se fortalecem mediante os laços sociais da simpatia e esta expande-se pelas relações sociais até toda a Nação ou Sociedade e afecta assim os costumes, os caracteres, acções, propósitos e relações entre os homens ${ }^{47}$. Deste modo se constrói uma regularidade que vai do plano sensorial, imaginário e passional até aos costumes, acabando por condicionar assim a uniformidade do gosto nas nações.

Montesquieu e Burke dão soluções diferentes para o problema da geração do novo e para o papel do gosto na sua observação. Onde o pri-

${ }^{47}$ E. Burke, A Philosophical Enquiry into the Origin of our Ideas of the Sublime and Beautiful, with an introductory Discourse concerning Taste, London, 1767, p. 29. 
meiro coloca a curiosidade como abertura do espírito ao novo e princípio do gosto, põe o outro autor a imitação como princípio da arte e a atenção ao objecto da percepção como a base de um juízo de gosto que, pela simpatia, se espalha na espécie humana logrando alguma uniformidade de sentimentos e juízos.

O Ensaio sobre o Génio (1774) de Alexander Gerard é uma reflexão de forma tratadística sobre a Psicologia do génio e pertence a uma fase madura das discussões sobre o conceito na Europa do séc. XVIII, em que os temas da novidade, surpresa e originalidade se encontram no cume. A definição central da obra de A. Gerard diz-nos que a primeira qualidade do génio é a invenção mediante a qual um homem consegue fazer novas descobertas em domínios tão diferentes quanto a ciência ou a arte (Genius is properly the faculty of invention) ${ }^{48}$. Podem detectar-se defeitos e erros, irregularidades, indisciplina e uma expressão selvagem em certas criações na ciência e na arte mas desde que nelas se exprima fundadamente algo de novo estamos perante "criações de génio". Vemos, portanto, como a oposição regra / invenção se generalizou de tal modo que, se não é o único critério de distinção entre o homem normal e o génio representa pelo menos uma demarcação obrigatória. $O$ critério da invenção vai exigir, contudo, que a consideração concreta do génio passe pela observação das suas composições e pela comparação com os predecessores. Mas sem afastar a ideia de um exame das composições como modo de aferir a invenção A. Gerard escolhe desenvolver o seu tratado à luz de uma investigação das faculdades da alma, da associação das ideias e do uso das faculdades, seguindo uma via claramente tradicional. A sua questão passa então a ser qual o poder do espírito que qualifica um homem com capacidade inventiva. $\mathrm{O}$ método do tratado prova a importância da representação psicológica das condições do génio mediante um argumento subjacente que consiste na tese de que a realidade de um efeito (a composição) está contida na capacidade de realização da sua causa (o génio). Entre as faculdades do espírito há umas mais ocupadas com a conservação da afecção sensorial e da percepção que outras. A imaginação é a faculdade mais capaz de combinar ideias já existentes de modo a torná-las novas e originais. Por isso, a imaginação deve ser contada entre as fontes imediatas da invenção e, por outro lado, it would appear, that genius of every kind derives its immediate origin from the imagination ${ }^{49}$. A imaginação tomada como fantasia não pode por si só garantir a fixação dos produtos da actividade do espírito. O que garante alguma estabilidade aqui é o que o autor chama juízo. Por juízo se entende uma conexão de

\footnotetext{
${ }^{48}$ A. Gerard, An Essay on Genius, London, 1774, p. 8.

${ }^{49}$ Idem, Ibid., p. 36.
} 
ideias para que contribuem em conjunto as faculdades do espírito e que pode ser objecto de avaliação. Segundo a sua interpretação da formação psíquica da invenção, é a imaginação que produz o génio e as outras faculdades assistem-na no trabalho de trazer os frutos da imaginação à maturidade. O génio é assim uma certa combinação da imaginação e do juízo. A diferença entre um homem cultivado apenas pela formação de bons juízos e o génio reside em que o primeiro se limita a receber a matéria das conexões das ideias de outrem ou da informação sensorial, é sempre heterocompositivo, ao passo que o génio é ele próprio a fonte das conexões de ideias sobre as quais ajuíza. Na verdade, A. Gerard enuncia aqui o princípio da individualidade do génio e a tese da sua auto-referência. Também prepara as teses de Kant sobre o génio e sobre a relação entre o génio e as "regras da arte".

$\mathrm{O}$ autor retoma na sua doutrina associacionista do génio a ideia do entusiasmo e define este último como uma certa "elevação e calor da imaginação" 50 . As notas da inspiração sobrenatural, do êxtase, do ardor fora de comum, do ímpeto, do vigor e da intensidade integram-se na sua explicação dos movimentos da imaginação no processo da associação das ideias do génio ${ }^{51}$.

O génio tem com o gosto uma afinidade evidente, que resulta de ambos serem fruto da imaginação. Esta ideia é já defendida no Ensaio sobre o Gosto (1759) do mesmo autor. As duas obras de A. Gerard combinam os dois temas mais relevantes da Estética do séc. XVIII, o gosto e o génio, derivando ambos do poder criador da imaginação e opondo os seus resultados à memória reprodutiva e à imitação. No Ensaio sobre o Génio a invenção e o génio são os autênticos produtores das regras da composição artística, o que se parece comprovar pelo facto de terem sido os génios de Homero e dos antigos escritores de tragédias que criaram as regras da epopeia e da tragédia como tal identificadas e reconhecidas depois por Aristóteles na Poética. O autor inverte assim a prioridade tradicional da regra em relação ao génio e faz deste a condição daquela.

$\mathrm{O}$ autor de umas Observations on Genius ${ }^{52}$ não obstante concordar com os tópicos da época relativos à proximidade entre génio e força da imaginação censurou A. Gerard por se ter dedicado a explorar o conceito de imaginação e a sua relação com as ficções da alma por meio das regras da associação das ideias. Diz-nos que as regras da associação de ideias são comuns a todos os homens e dificilmente podem ser tomadas por

\footnotetext{
${ }^{50}$ Idem, Ibid., p. 67.

${ }^{51}$ Idem, Ibid., p. 68-69.

52 William Belsham, "Observations on Genius" in Idem, Essays, Philosophical, Historical, Literary, "Essay XX”, London, 1789, pp. 383 e ss.
} 
base do que caracteriza o génio do homem extraordinário. Aceitando a proximidade entre génio e entusiasmo, o autor desenvolve algumas notas em que considera que na História do conceito de génio só recentemente ele foi associado ao entusiasmo. Há uma ligação mais antiga e tradicional do génio à melancolia que interessa tratar. Mas logo nos diz que entre a melancolia e o entusiasmo parece existir uma aparente contradição ${ }^{53}$. Ao contrário do entusiasmo, a melancolia parece deixar o corpo sem iniciativa e sobretudo sem o ardor tão típico do entusiasmo e que acompanha a expressão expansiva do génio. A melancolia parece-lhe uma consequência evidente do desapontamento e da falta de iniciativa. A crítica a A. Gerard volta-se igualmente para o critério da invenção, considerado demasiado estreito e limitador para integrar todos os aspectos em causa na formação e expansão do génio. Entre muitas das capacidades e faculdades do espírito que devem ser atribuídas ao génio na sua constituição deve estar também o gosto, argumenta o crítico ${ }^{54}$. Na tese do ensaísta, se admitimos que o gosto faz parte do génio esta nossa ideia pode tornar-se incompatível com a definição do génio pela nota da invenção. Claro que ele tem em mente uma grande proximidade entre gosto e respeito pelo uso adquirido de regras. De um modo vago, o gosto é definido como uma capacidade de apreensão da beleza e "ardente admiração da mesma". Reconhece, não obstante, que uma coisa são as faculdades que tornam alguém apto para admirar ou discernir uma coisa e outras aquelas que se requerem para criar. Mas das suas críticas não resulta uma ideia clara sobre a diferença entre gosto, génio e invenção como critério do génio.

Para nós, o carácter incompleto e de certo modo contraditório do método de A. Gerard deriva de o autor supor que pode garantir um critério psicológico da invenção e uma concepção psicológica do gosto quando ambos supõem juízos comparativos, a analogia, não apenas no sentido interno ou resultante da associação de ideias, mas implicando uma relação social. As suas teses revelam o impasse de uma descrição dos conceitos de gosto e de génio com referências exclusivamente psíquicas. No caso do gosto, particularmente, as suas ideias do Ensaio de 1759 perdem em capacidade de persuasão para a concepção marcadamente social de que parte o pintor Allan Ramsay no seu A Dialogue on Taste (1762) ao fazer depender o critério do gosto de "standards" de juízo estético adoptados na vida social e associados ao "senso comum" dos homens. A. Ramsay e antes dele E. Burke tornavam explícito o que na análise de A. Gerard ainda se encontrava encoberto: o facto de não ser possível uma concepção completa das regras do juízo estético, do gosto e da composição da obra de

\footnotetext{
53 Idem, Ibid., p. 397.

54 Idem, Ibid., p. 391.
} 
arte sem um conceito do público, da simpatia ou do senso comum. Estas últimas noções encontravam-se, contudo, ligadas à vigência de regras, ao standard e a simpatia aparecia com um significado conservador. É aqui que podemos verificar como a imaginação, a inovação e o entusiasmo são marcas psíquicas de um interesse comunicativo pelo novo que a sociedade não deixa de suscitar, mas para o qual não há ainda uma madura explicação social. Foi esta situação que nos levou a dizer que na semântica do gosto e do génio, da época, se ilustra como a sociedade é a face virtual da consciência e dos predicados psíquicos.

Os dois ensaios de A. Gerard tiveram um grande impacto público e foram traduzidos para alemão na época de pico da discussão alemã dos temas associados ao génio e ao entusiasmo: em 1766 o Ensaio sobre o Gosto e, em 1776, o Ensaio sobre o Génio. As duas obras vieram aumentar a corrente de recepção da literatura francesa e inglesa sobre os temas. Em França, da autoria de Voltaire, de d' Alembert e de Montesquieu conhecemos escritos sobre o gosto e sobre o génio, sobre o lugar do génio de Shakespeare na arte dramática que foram também recebidos e discutidos na Alemanha. No artigo "Génie" da Encyclopédie o gosto aparecia investigado ao lado do génio. Partindo destes elementos é-nos possível concluir que os temas do gosto e do génio estão fortemente emparelhados na cultura literária e filosófica do século XVIII, francês, inglês e alemão e sempre associados a doutrinas psicológicas, especialmente sobre o papel da imaginação e do sentimento de si.

A importância que tem a representação do novo nas discussões cruzadas sobre o gosto e o génio é muito evidente ainda nas reconstruções teóricas da época sobre o progresso e o sentido da História, em A. Ferguson no Essay on the History of Civil Society (1767) ou em I. Iselin no Über die Geschichte der Menschheit (edição melhorada, 1770).

\section{Formas sociais do génio}

\subsection{A ideia do génio poético nacional}

A recepção de Shaftesbury na Alemanha não se pode separar do tema da relação entre mundaneidade e interioridade do sujeito que é um tema habitual nos círculos pietistas. Por outro lado, na linha que leva de Shaftesbury a Herder e a Goethe encontramos o conceito de génio e o problema da relação entre génio e Bildung. O interessante a notar é que a influência de Shaftesbury em Inglaterra acaba por sofrer com a visão do mundo dos seus escritos, pouco adequada ao empirismo, ao passo que a 
sua presença na Alemanha é cada vez maior ao longo do século XVIII e progressivamente associada ao desenvolvimento do sentimento romântico. De lembrar que Herder tem referências directas a Shaftesbury e em 1800 traduzia deste o "Hino à Natureza". Mas a quantidade de referências directas e indirectas que na Alemanha vão na direcção da obra do terceiro conde de Shaftesbury é impressionante e reveladora de um caso de moda intelectual ${ }^{55}$.

Na Alemanha do início do século XVIII a escola de Leibniz-Wolff permitia conclusões próximas às de Shaftesbury no que se refere à compreensão da tarefa da educação na formação moral e estética do Homem na direcção da perfectibilidade. A Metafísica da Perfeição não era contrária à aposta no desenvolvimento de uma autonomia do juízo moral e estético do sujeito, como a exigida pelo programa de Shaftesbury. Com a obra de Baumgarten a disciplina de Estética na Alemanha identifica-se com um exame semelhante das faculdades cognoscitivas e da capacidade de sentir do Homem e está também ligada a uma apreciação positiva do sentimento.

Pierre Coste foi um autor e tradutor de literatura inglesa para francês e correspondente de Leibniz ${ }^{56}$. Por intermédio dele Leibniz ficou a par da Carta sobre o Entusiasmo e a seu pedido terá escrito observações sobre este trabalho de Shaftesbury com um tom positivo. Sobre as Caracteristicas Leibniz escreveu também comentários positivos.

Mas a atitude de Leibniz relativamente ao "bom humor" como política contra os entusiastas é mais relativa e branda, pois afirma que o seu alcance é menor do que aquilo que o escrito de Shaftesbury lhe atribuíra. Para Shaftesbury a relação entre o "ridículo" e o "sério" era ela mesma uma relação e uma diferença que devia ser revelada mediante o "ridículo", o que naturalmente é difícil de regular.

No projecto filosófico de Herder a questão do valor do sentimento na sua relação com a razão está já claramente presente, do mesmo modo que em Schiller. Isto quer dizer que o exame do papel do sentimento moral

55 As edições de referência das Características de Shaftesbury são as de 1743, 1758, 1773 e 1790. Em 1769 publicavam-se umas “Obras” em Genebra. Diderot em 1745 e 1751 divulgava o autor junto do público francês. No caso da Alemanha, as reflexões sobre o humor, com referência a Shaftesbury, de Leibniz, datam de 1709 e 1711. J. C. Gottsched traduz para o alemão alguns textos $(1738,1746,1748)$. Em 1745 é traduzido o texto dos "Moralistas", em Berlin, por J. J. Spalding. F. C. Oetinger traduz também alguns excertos (1753) e J. G. Hamann verte a Carta sobre o Entusiasmo e o "Senso Comum" em 1755. Para C. M. Wieland, Lessing e Mendelssohn Shaftesbury será uma referência decisiva. A tradução em alemão das Características aparece entre 1776-79 e, da responsabilidade de Herder, uma tradução do "Hino à Natureza" é publicada em 1800.

${ }^{56}$ R. Horlacher, op. cit., p. 28 e 34. 
é decisivo para um conjunto diversificado de aspectos da vida social que se encontravam subordinados na significação sincrética do "juízo moral". Nas Filosofias e reflexões pós-kantianas de Schelling, Hölderlin e Hegel o exame da reavaliação do papel do sentimento continua a desenrolar-se. Neste novo contexto a linha de recepção dos pensamentos de Hemsterhuis e de Jacobi será de grande importância.

A Lettre sur l'Homme et ses Rapports de F. Hemsterhuis ${ }^{57}$ começa por atribuir uma grande importância ao processo sensitivo por meio do qual o homem recebe ideias dos objectos existentes fora da mente e as associa com a existência extra-mental. A sua perspectiva do processo sensorial não se desliga da ideia de um movimento universal perpétuo que, segundo a relação causa-efeito, inclui em si a própria sensação como um dos seus tipos, embora a vontade deva ser excluída. De modo a dar conta da retenção das ideias de proveniência sensível no sujeito para as comparar com outras ideias introduz o autor o conceito de signo. O recurso a signos na vida mental tem lugar sempre que é necessário realizar comparação entre ideias. Os signos primitivos são constituídos pelos efeitos dos objectos nos órgãos sensoriais, pois são estes efeitos que se consideram no lugar da própria coisa. A invocação do signo pode então servir para voltar a colocar na mente a ideia que originalmente esteve associada à sensação. O raciocínio está intimamente ligado à capacidade do espírito para relacionar ideias através de signos e de voltar a fazer presente ao espírito a causa das ideias. Neste voltar a tornar presente o raciocínio junta-se à intuição. Para Hemsterhuis o génio consiste na faculdade de tornar novamente presente as ideias grandes e mais afastadas do espírito.

A diferença entre o homem e o animal reside no facto de o animal não usar signos arbitrários. Mas também o uso da vontade no homem revela-nos um ser capaz de iniciativa e de iniciar a partir de si mesmo movimento. Neste último aspecto Hemsterhuis considera que não é possível rejeitar o princípio da liberdade e espontaneidade no Homem. Mas no caso do homem como no animal a alma precisa ser provocada na sua faculdade volitiva pela acção e reacção com a realidade externa ou com outros animais e homens. Sem o jogo da acção e da reacção também não é concebível a liberdade ou a espontaneidade.

O ponto de partida da relação do eu com a realidade exterior e mesmo com Deus é o indivíduo ou o eu como indivíduo, portanto como um ser separado mas capaz de sentir por intermédio dos seus órgãos. Hemsterhuis alarga a sua ideia inicial do indivíduo separado para incluir uma perspectiva sobre o universo moral e social dos homens. Porém, para conceber a relação social entre as vontades distintas dos indivíduos ele tem de

${ }^{57}$ F. Hemsterhuis, Lettre sur l' Homme et ses Rapports, Paris, 1772. 
mostrar em que consiste e como se organiza o órgão capaz de relacionar os indivíduos uns com os outros em sociedade. Este órgão, a que também chama "coração" 58 , tem de ser caracterizado por uma abertura ao estranho de modo a permitir a recepção das outras vontades. É por conseguinte também passivo. O mais importante a notar é que deste órgão faz parte o próprio eu que é, ao mesmo tempo, vontade e passividade. Este órgão não dá ao homem apenas o que as coisas são fora dele mas ainda o modo como o eu se sente afectado por elas e isto ocorre especialmente quando essas "coisas" são outras vontades.

Para comunicar em sociedade os signos comunicativos juntam-se a este órgão voltado para a sensação moral do mesmo modo que os signos não comunicativos serviam para estabelecer as comparações das ideias recebidas pelas sensações dos objectos externos. Mediante os signos comunicativos os homens transmitem uns aos outros em sociedade as mesmas ideias que apreendem na experiência sensorial e é possível então esperar que os movimentos da alma de um indivíduo se passem a assemelhar aos movimentos dos demais que com ele entraram em comunicação. Os signos comunicativos desempenham a função de retomada das mesmas ideias presentes nos órgãos sensoriais. Na medida em que os signos comunicativos transmitem as mesmas ideias e as mesmas reacções em todos os homens é de supor que no início da História humana todos falassem uma mesma língua, mais próxima da forma natural da sensação e do processo ideativo e reactivo da espécie à forma como os primeiros movimentos se imprimiram nos órgãos sensoriais. Os signos comunicativos são aqueles que asseguram a repetição da impressão dos movimentos nos órgãos dos sentidos em outros indivíduos. Deste ponto de vista, a linguagem é um meio de transmissão de ideias que afectam comummente o que o autor chama "órgão moral". O "órgão moral" que está voltado para a face moral do universo está por seu lado associado com os órgãos da apreensão sensorial e é possível relacionar a apreciação positiva e negativa da experiência nestes últimos órgãos com a apreciação moral do bem e do mal, da virtude e do vício. As diferenças nas concepções do belo e do feio, do bom e do mau, do agradável e do desagradável resultam do modo como o indivíduo se situa na sociedade por meio do órgão moral e da elaboração intelectual do que este órgão recebe. A formação nos indivíduos dos conceitos dos deveres está relacionada não só com o que se imprime no órgão moral mas também com a sua constituição particular.

Hemsterhuis diz que se trata de uma diversidade na capacidade sensitiva do órgão. Quanto mais sensível for o órgão moral na relação social mais deveres o indivíduo pode conceber para com os demais. Daqui se

${ }^{58}$ Idem, Ibid., p. 30. 
seguem várias consequências sobre o entendimento do papel da religião a que o autor empresta um espaço considerável na sua carta.

As ideias de Shaftesbury, dos escoceses e de Hemsterhuis sobre um sentido moral ligado à sociedade e à socialização, o "órgão moral" deste último, possuem um momento importante de concretização na obra de Schiller. Do ponto de vista poético, graças à retomada do tema do coração Schiller está muito próximo dos temas românticos. Mas nas "Cartas sobre a Educação Estética do Género Humano" a sua proposta vai claramente no sentido do reconhecimento de um papel central à sensibilidade na formação do conhecimento ético, o que justifica a sua atribuição à arte do valor de guia na educação da humanidade. Ora, aqui está presente o programa de Hemsterhuis.

A evolução do conceito de génio torna manifesta a evolução desde um conceito expressivo até uma modalidade da auto-referência formal na Estética kantiana. As bases da ideia de génio na individuação expressiva ligam o conceito às significações associadas ao querer-dizer da intencionalidade que não se limita ao domínio da subjectividade mas se alarga à totalidade da natureza e dos significados culturais das vidas dos povos. De acordo com esta forma expressiva do querer-dizer "natural" e "cultural" o génio representa o equivalente a um medium no qual se efectivam e individualizam as forças que de outro modo dificilmente se concretizariam. $\mathrm{O}$ génio é, pois, o instrumento luminoso das forças que se querem exprimir, é o equivalente a uma voz. Com ele e por ele a natureza e o espírito dos povos encontram o seu caminho para a evidência.

Como consequência da mentalidade nacionalista e romântica, na segunda metade do séc. XVIII assiste-se ao retorno às raízes das literaturas nacionais e à descoberta do uso mais primitivo das línguas maternas no que pode ser entendido como poesia nacional. $\mathrm{O}$ caso muito discutido e divulgado do bardo escocês Ossian é exemplificativo. $\mathrm{O}$ autor dos poemas forjados atribuídos ao poeta "nacional" escocês Ossian, que teria escrito no recuado séc. III uns versos em baladas, foi James MacPherson. A apelidada "tradução" dos versos fora publicada inicialmente em 1760 e depois em 1765. Numa nova edição destes poemas, publicada em Londres em 1796, o autor-tradutor desenvolve considerações sobre a relação entre o génio e a língua, sobre o génio e o gosto ou sobre o valor da inspiração pelas musas para a descoberta da recta composição poética.

Nos ensaios críticos apensos à sua "tradução" James MacPherson entra em pormenores sobre o significado do recuo à Antiguidade para encontrar os tesouros linguísticos dos povos, muitas vezes misturados com fábulas, que exprimem o seu verdadeiro carácter. Em A Dissertation concerning the Poems of Ossian J. MacPherson localiza no tempo e na Geografia os poemas de que se apresenta como tradutor. Tratar-se-ia de poemas trans- 
mitidos oralmente desde longínquos tempos relacionados com histórias dos povos do norte da Europa, entretanto perdidos. A razão para a perda de interesse nestes documentos está em grande medida na tendência das nações romanizadas para considerarem como "bárbaro" todo o património cultural proveniente do Norte da Europa. O "tradutor" de Ossian propõe-se restabelecer a dignidade dos povos nórdicos ou bárbaros entre as restantes nações da Europa. Para isso vai desenvolver uma contra-narrativa para substituir a versão nórdica do grego-romano / bárbaro à distinção latina do grego-romano / bárbaro.

Segundo a contra-narrativa as nações bárbaras do norte da Europa mantiveram a frescura e a força necessárias às "nobres paixões da alma" que entretanto se haviam perdido nas "nações polidas", em virtude do seu próprio progresso e refinamento. A conservação desta força espiritual garantiu protecção contra a perda de energia nas nações refinadas. As histórias, poemas e fábulas de épocas muito recuadas mantêm a memória do carácter dos povos na sua força inicial.

J. MacPherson não só forja o material que comunica o espírito da História antiga como ainda se serve da sua própria criação para conceber os laços entre o oral e o escrito, entre o bárbaro e o greco-latino, entre nações polidas e o génio das "paixões nobres" dos povos que não conhecem a escrita literária. Nele, a literatura é serva dos caracteres nacionais mais próximos daquelas paixões imprescindíveis para acender de novo o génio, no seu carácter selvagem e incontaminado, retendo na forma da comunicação oral o que esteve mais próximo da origem, por exemplo na relação entre a forma vocal e o canto. J. MacPherson foi consequente com a sua visão do canto das gentes das Highlands ao compor os textos numa forma que cuidadosamente repõe a comunicação oral em que alegadamente as fontes se haviam gerado. Naturalmente, este imperativo de obedecer à forma oral está associado ao mito da autenticidade e daqui é fácil partir para a concepção de uma conservação da História viva das nações no canto e no poema. A diferença entre o bárbaro e o polido é assumida e integrada na diferença histórica entre o antigo, como monumento pré-escrito, e a civilização resultante do mundo greco-latino.

Na reconstrução dos poemas e do seu autor, Ossian, pelo crítico Hugh Blair, um contemporâneo de J. Macpherson, pode ler-se uma descrição do génio "nacional" ou tribal que inspirou o bardo e por si só muito significativa: Ossian himself appears to have been endowed by nature with an exquisite sensibility of heart; prone to that tender melancholy which is so often an attendant on great genius: and susceptible equally of strong and of soft emotion. He was not only a professed bard, educated with care, as we may easily believe, to all the poetical art then known, and connected, as he shows us himself, in intimate friendship with the other contempo- 
rary bards, but a warrior also; and the son of the most renowned hero and prince of his age ${ }^{59}$. Nesta descrição temos reunida uma parte muito exemplificativa dos elementos semânticos caracterizadores da imaginação e da semântica do génio e do génio "nacional" em particular.

$\mathrm{O}$ génio poético de Ossian deve muito às condições da sua época e do seu país. Mas H. Blair sublinha de novo a dualidade do melancólico e do entusiasta, sem referir esta última palavra. Na realidade o crítico vai mesmo mais longe e interpreta a força vital do génio como um ditame da sua postura heróica. O génio poético é, assim, melancólico e heróico. Para entender esta associação é preciso reter a relação entre heroísmo e poesia. É na fama que o herói encontra algum reconhecimento pelos seus feitos corajosos. Mas a fama é pelo canto do bardo proclamada e depende, portanto, para ser imortalizada, do génio poético. O crítico assinala assim um nexo entre o lado activo e irascível do guerreiro e o aspecto melancólico do bardo, mas também a concretização de ambos os lados no mesmo carácter, graças à sua ideia do bardo-herói. A abundante utilização do termo coração (heart) serve para identificar a sensibilidade especial do bardo e a sua capacidade de a comunicar.

A ideia de inspiração foi analisada por J. Grimm na sua Mitologia como significando um dom dos deuses e mostrou como o poeta ou o cantor só podem obter a força para produzirem o canto ou o poema de fora deles mesmos. A relação entre a voz interior e a voz externa, endividada aos deuses ou à pátria, forma a dualidade que atravessa todo o conceito de génio. Daqui se infere uma parte do significado da noção de entusiasmo do indivíduo excepcional como gottbegeistert. Em concordância terá nascido a crença da inspiração como voz interior que depende da devoção aos deuses nativos das terras germânicas. Entre essas divindades estava "Saga". Aqui se percebe como o sentido da comunicação com o além, divino, diabólico, inter-psíquico ou comunitário, se funda na concepção do espírito como um quase-fantasma, como alma penada, situada entre vários reinos ou domínios.

A língua alemã conservara no século XVI o termo latino Genius, só substituído no século XVIII pelo francesismo Genie. Mas Genie esteve sempre muito próximo no seu uso e significado do outro termo alemão, Geist. Geist designava o equivalente a uma voz interior que falava da profundidade do sujeito pondo a nu os seus segredos. A respeito disto não se estranha o parentesco de Geist e de Geheimnis.

No sec. XVII o termo Genie aplica-se também a povos, a colectividades étnicas e à língua. Os irmãos Grimm criam condições únicas para o

${ }^{59}$ Hugh Blair, A Critical Dissertation on the Poems of Ossian, the Son of Fingal, London, 1763, p.15. 
desenvolvimento na cultura alemã do Geist nesta acepção que não cessa de se aprofundar até chegarmos a Goethe e à sua representação do rapto da alma do homem criador por uma entidade que lhe é alheia, como acontece na apropriação da história e lenda do contrato entre Fausto e o Diabo.

\subsection{Herder e Kant: um modelo orgânico e um modelo formal do génio}

Em Über den Fleiß in mehreren gelehrten Sprachen refere Herder a época de ouro da História da Humanidade em que os povos ainda não se haviam dividido em línguas e em que dominava uma satisfação geral com a própria condição natural. Desta situação evoluiram as línguas e os povos para a dispersão geral, que é actualmente a norma, e que faz com que a cada língua corresponda um carácter nacional. No entanto, Herder tece várias considerações sobre a correspondência expressiva do carácter popular e das línguas nacionais ${ }^{60}$, a respeito dos caracteres grego, romano ou germânico. Nas línguas nacionais não só se exprime o modo-de-ser dos povos mas ainda as formas de pensar e de reconhecer a realidade assim como os conceitos essenciais. Em escritos da mesma época considerava Herder como integrantes da língua nacional a beleza, o "gosto" e o "espírito".

Nas introduções da sua recolha de poemas e canções populares dos povos nórdicos e do sul da Europa viu Herder em especial nos poemas de Ossian expressões genuínas não de um autor, do poeta, mas do génio ou alma do povo. As suas ideias sobre a criação popular estendem-se à mitologia dos povos nórdicos incluindo a mitologia alemã. O povo é concebido como uma colectividade que é tanto mais genuína quanto mais próxima estiver de um estado selvagem, pré-civilizada ou, pelo menos, num estado anterior ao conhecimento das virtudes e refinamentos do homem civilizado $^{61}$. A diferença entre o "selvagem" e o "civilizado", o "selvagem" e o "artificial", o "erudito" ou o "artístico" percorre todas as considerações do autor sobre o valor de Ossian e dos poetas nacionais antigos frente à literatura dos modernos, como um eco do binário de Rousseau, que voltaremos a encontrar, mais tarde, nas Cartas sobre a Educação Estética de Schiller na distinção entre "selvagem" e "bárbaro". O texto de Herder em que comparou a noção de público das sociedades antigas e das modernas mostrava como o povo não se podia considerar uma autêntica colectividade, vital e actuante, nas condições sociais e políticas da modernidade.

${ }^{60}$ J. G. Herder, Sämmtliche Werke, Bd. 1 Zur Schöne Literatur und Kunst, Carlsruhe, 1821, p. 2.

${ }^{61}$ Idem, Stimmen der Völker in Lieder, Wien, 1813, pp. 13-14. 
As formas de expressão dos povos que mais próximas estivessem do estado selvagem eram por ele consideradas também as mais vivas, livres, sensíveis e líricas e deviam considerar-se modos de uma língua primitiva (Ursprache $)^{62}$. Os exemplos vão para os antigos escoceses, os escandinavos, mas também para os habitantes da América do Norte, conhecidos à luz dos relatos dos viajantes. Estas expressões primitivas também são as mais afastadas da letra morta da versificação moderna e da organização moderna da matéria rítmica. O canto é a sua forma privilegiada. As canções populares são mesmo vistas como um "arquivo dos povos" 63 em que se conserva não apenas o sentimento rítmico, mas concepções religiosas e científicas, a mitologia, os feitos dos antepassados e os acontecimentos históricos tal como foram vividos. O ouvir e a memória relacionada com a audição constituem as formas que conservam mais adequadamente a vitalidade da expressão lírica dos povos, como é o caso com a música, o canto, a poesia, a dança, etc. Trata-se em todos estes exemplos das artes do ritmo. Graças ao ritmo, a canção e o poema exercem uma influência duradoura na escuta sensível dos seus leitores modernos, levando estes à percepção da força selvagem dos povos antigos. Por outro lado, o ritmo permite associar as formas sensíveis do sentimento popular, a narração da gesta e a escuta numa única corrente psíquica. É aliás esta unidade que Herder considera como mais digno de apreço na lírica dos povos selvagens. Nesta corrente psíquico-rítmica repousa a concepção de cultura e a noção de cultura como facto histórico da vida dos povos. No entanto, o que Herder encontra nesta ideia não é nada de equivalente a um modelo a ser imitado, mas sim a própria natureza desses povos ${ }^{64}$. Quer dizer que as expressões da vida colectiva contam directamente como expressões da natureza (sensível) dos povos selvagens, mediante uma identidade entre palavra, pensamento e sentimento, e que a intelectualização dessas expressões só pode mutilá-las, como claramente se demonstra pelo empobrecimento erudito do seu significado original. O que destrói esta força primitiva da natureza é a arte e o artifício. A oposição entre artifício (ou arte) e natureza reflecte-se ainda no facto de Herder considerar que os poemas e melodias dos povos selvagens são criações espontâneas que captam o momento, como impromptus ${ }^{65}$. O génio criador não consiste em outra coisa a não ser na captura desta presença sensível na modalidade do momento oportuno atravessado pela inspiração. A unidade psíquico-rítmica da significação poética supõe também esta espontaneidade do presente da

\footnotetext{
62 Idem, Ibid., p. 18.

63 Idem, Ibid., p. 62.

64 Idem, Ibid., p. 26.

65 Idem, Ibid., p. 27.
} 
inspiração. Vitalidade e espontaneidade na criação são, pois, mais dois elementos que se alinham do mesmo lado do carácter natural e selvagem da alma dos povos antigos, que é cantada pelos bardos inspirados. Recuperando o dito horaciano ut pictura poesis Herder afirma a ideia de que o poeta-cantor dos povos selvagens parte de imagens e não de conceitos, a sua alma está repleta de retratos vivos de acontecimentos e cada parte dos seus poemas tem correspondência nas partes de uma imagem viva ${ }^{66}$, por isso o poeta selvagem não discorre no sentido intelectual do termo, mas pinta directamente as imagens da imaginação.

Herder irá comentar os poemas de Ossian, vendo neles expressões representativas do espírito nacional de um povo. Mas as suas referências ao génio nacional nórdico ainda incluíam Shakespeare e um conjunto de ideias sobre a diferença entre o drama nórdico e a tragédia grega clássica. O ensaio sobre Shakespeare e as cartas sobre Ossian revelam como Herder pretendera integrar o conceito do génio individual na corrente criativa do povo e como este último fazia ainda parte da totalidade da natureza como força expressiva. Claro que a sua visão tinha de juntar uma concepção metafísica da totalidade do Homem e da Natureza e a tese da unidade expressiva dos diferentes órgãos que compõem esse todo. Para ela contribuiu a tese do "Uno-Todo" da tradição antiga recuperada com as vestes do espinosismo.

No diálogo Gott, como uma resposta às cartas de Lessing, Herder pretendera corrigir a ideia muito difundida que fizera de Espinosa apenas um ateu. No diálogo, os personagens passam em revista todos os pontos do sistema de Espinosa, mas um dos aspectos que merece especial atenção é o da relação simbólica que liga os seres finitos à substância infinta de Deus ${ }^{67}$ que se identifica com uma harmonia ou harmonia simbólica.

Relativamente à concepção da operação de Deus na natureza, Herder recorre ao conceito de força e de uma capacidade de especificação do Uno na multiplicidade mediante as forças. A relação do Uno com a multiplicidade por meio das forças constitui-se ainda mediante uma expressão orgânica ${ }^{68}$. O organismo é aliás a ideia mais indicada para exprimir este nexo. Para poder compreender o conceito de força e a sua relação com a causalidade o autor compara os sistemas de Leibniz e Espinosa. As concepções defendidas nos diálogos finais são uma combinação de teses organicistas e psico-expressivas, em que se dá um grande relevo ao papel da alma na animação de uma totalidade orgânica. O corpo é tomado

\footnotetext{
66 Idem, Ibid., p. 40.

67 J. G. Herder, Gott. Einige Gespräche über Spinoza's System, nebst Shaftesburi's Naturhymnus, Gotha, 1800, pp. 83-84, 94.

${ }^{68}$ Idem, Ibid., p. 248.
} 
como expressão da alma. Mas ao lado do conceito de expressão e de uma totalidade psiquicamente comandada o autor concebe a ideia de força. É graças às forças que a totalidade orgânica se caracteriza como totalidade expressiva. A beleza, o bem e a harmonia são alguns dos predicados da ordem que resulta desta expressão orgânica de Deus na Natureza ${ }^{69}$. Da organização total da natureza e da dependência universal de cada uma das suas partes em relação às demais se conclui que a morte e a destruição de partes desse todo é uma consequência forçosa da ordem geral. A cada ser limitado e finito corresponde uma determinada destruição e a cada destruição corresponde um outro florescimento. Cada ser limitado na natureza expande-se até um limite de determinações que coincide com o que a sua essência pode produzir de perfeição e de beleza, na passagem do caos para a ordem ou da força cega para a força expressiva, para logo dar origem a um processo de decadência e destruição ${ }^{70}$. A natureza não contém nem paz nem repouso. Nela tudo se desenvolve entre nascimento e destruição. A hipótese da palingenesia universal na natureza é uma boa ideia para sustentar um poder de destruição, renovação e rejuvenescimento de todas as coisas. Desta ideia geral pode então partir-se para o enunciado de um conjunto de teses sobre a organização interna da natureza como composição expressiva interna de forças. De um ponto de vista muito geral que pode considerar-se apropriado a sistemas tão diversos como o de Espinosa, Leibniz ou Shaftesbury, o pensador conclui que deve chamar-se individualidade à expressão finita das modificações da substância ${ }^{71}$. $\mathrm{O}$ conceito de individualidade representa a síntese de dois aspectos: o que se refere à modificação finita da substância e o outro que diz respeito à permanência ou identidade do mesmo. Este ultimo é o que ele designa por princípio da mesmidade ${ }^{72}$, que aliás aproxima do princípio da individuação, propriamente dito, a ponto de confundir ambos. Individuum e Selbst são o mesmo. Quer dizer que o que garante a perdurabilidade de um existente a partir do que define esse mesmo existente é a sua individualidade ou o seu si mesmo. Neste caso, o si mesmo e a energia para perdurar no seu próprio ser se identificam também.

O espinosismo serviu aos defensores de uma visão totalizante da natureza e aos teóricos da "Naturphilosophie" de inspiração mais marcadamente romântica como uma ideologia restauradora das Metafísicas especiais e das ambições das explicações integradoras para além da resistência céptica ou da timidez criticista. Mas, no caso de Herder, o espinosismo

\footnotetext{
${ }^{69}$ Idem, Ibid., p. 274.

${ }^{70}$ Idem, Ibid., p. 279.

${ }^{71}$ Idem, Ibid., p. 292.

72 Idem, Ibid., p. 295.
} 
não é incompatível com um humanismo. No ideal da Igreja invisível vê o pensador a condição de uma única Humanidade emancipada das divisões entre nações ou das diferenças étnicas, concebida à luz da noção de uma "sociedade da humanidade". A socialidade é a base da Humanidade, acrescenta o autor nos seus comentários às ideias e ao exemplo de B. Franklin nas Cartas em defesa da Humanidade ${ }^{73}$. O esclarecimento sobre o que é a socialidade informa-nos que esta é equivalente a uma comunicação interpsíquica, representando uma autêntica corrente anímica. Os conhecimentos humanos adquiridos em livros podem ser comunicados em comunidade, mas esta transmissão depende sempre da oralidade. O discurso oral é imprescindível e é a ele que se atribui a principal responsabilidade na reprodução dos laços da comunidade humana que são preferencialmente laços de fraternidade. Só a oralidade pode impedir a escrita de se tornar letra morta. Ao lado da oralidade e como seu complemento natural coloca o autor a acção. Podemos concluir, portanto, que o verdadeiro espírito da humanidade será mais oral e actuante do que escrito ${ }^{74}$. A defesa do princípio da oralidade na formação da sociabilidade humana tem uma relação óbvia com a ideia, sustentada no mesmo escrito, de que a fraternidade vivida em certas sociedades secretas antecipa a forma global da fraternidade humana, é como o microcosmos desta última. Onde a sociabilidade encontra um terreno fértil para se desenvolver descobre-se também um solo propício ao patriotismo. Em consequência, os poetas e artistas que produzem os seus trabalhos em consonância com a alma popular são os mais estimáveis e os que perduram no espírito dos leitores. A comunicação poética é feita de "coração a coração" a partir de uma voz colectiva que exprime os anseios das nações e o "espírito do tempo"75.

O texto retoma a ideia de uma corrente psíquico-rítmica-acústica, desta vez tomando como autor a entidade colectiva chamada "povo" ou "nação". Nesta corrente psíquico-acústica, o génio poético consiste na boa apreensão da "voz do tempo"76 coincidente com o espírito da época. Entre as suas observações o autor das Cartas interroga-se a que realidade empírica poderá corresponder a expressão Geist der Zeit e entre as hipóteses que coloca estão um "génio", o próprio "génio da humanidade", um "daimón", um "poltergeist", uma alma penada regressada dos mortos ou um sopro da moda passageira. $\mathrm{O}$ ensaio de concretização empírica do "espírito do tempo" é na prática impossível de realizar sem destruir o próprio conceito. Uma das razões de ser desta dificuldade está na própria

\footnotetext{
${ }^{73}$ Idem, Briefe zu Beförderung der Humanität, Riga, 1793, p. 21.

${ }^{74}$ Idem, Ibid., p. 23.

75 Idem, Ibid., p. 162.

76 Idem, Ibid., p. 171.
} 
noção de "espírito". As notas distintivas da ideia antiga de espírito associam-no à vitalidade e à força ou a um poder invisível. Em oposição ao corpo o espírito foi reconhecido pelos antigos como uma capacidade de penetração vital das partes no sentido de dar uma ordem e orientação aos membros dispersos ${ }^{77}$. A noção de tempo é por Herder analogada à série dos pensamentos e à sua orientação na consciência. Da conjugação das duas ideias resulta que o "espírito do tempo" é "a suma dos pensamentos, dos sentimentos, anseios, pulsões e forças vitais que se exteriorizam num determinado curso das coisas na presença de certas causas e efeitos"78.

A concretização de um tal "curso" dá-se forçosamente em situações definidas por um "local". O "espírito do tempo" não existe, por conseguinte, sem localização. É por isso que, nas suas observações, passa da definição do conceito segundo a nota do fluxo (de pensamentos, de sentimentos, etc.) para a localização geográfica do "espírito do tempo". Para o que lhe importa, o "espírito do tempo" ocorre na Europa. A localização opera no "espírito do tempo" como um elemento diferenciador. Mas na medida em que no tempo o espírito perpassa na diversidade das suas expressões nos diferentes povos, épocas e nas diferentes regiões, é então possível apreender a unidade desta diversidade, a que o pensador chama Iluminismo (Aufklärung) ${ }^{79}$ e que resulta de uma comunidade espiritual. A comunidade dos iluminados é aquela para o qual o "espírito do tempo" faz sentido. A sintonia entre os iluminados e o "espírito do tempo" é feita pela mútua pertença a um ímpeto que se exprime no sentimento. Trata-se de uma proximidade subjectiva e inter-subjectiva.

É também esta a justificação para a atribuição ao "espírito do tempo" do equivalente a uma pulsação que se desenvolve entre os indivíduos que o percepcionam. Nela participam todos os heróis e génios das épocas passadas como membros de uma comunidade de seres pensantes, a que também chama "Igreja invisível" ou "sociedade ideal" no diálogo final sobre a "sociedade invisível e a sociedade visível"80. Aqui, o filósofo termina a sua exposição de uma defesa da Humanidade com o seu conceito de sociedade. Para introduzir este último vai ser decisiva a ideia de que a Humanidade só se completa na relação do indivíduo com outros indivíduos. Mas como? A sua resposta dirige-nos para uma comunicação especial, do "coração para o coração". É esta que concretiza a ideia de uma sociedade humana como comunicação inter-psíquica em que a percepção de um está, ou pode estar, associada às percepções internas dos

\footnotetext{
77 Idem, Ibid., p. 14.

78 Idem, Ibid., p. 14.

${ }^{79}$ Idem, Ibid., pp. 16-17.

${ }^{80}$ Idem, Ibid., pp. 146-147.
} 
outros ou, o mesmo que dizer, a co-genialidade. Nestas ideias, Herder reconstrói uma das mais antigas concepções sobre a arte e a sociedade, precisamente a que partia da noção de nexo mimético e que fazia repousar a mimesis na capacidade de incorporação do personagem pelo poeta ou pelo "rapsodo", na mesma expressão co-genial.

As reacções de Kant às teses de Herder tomam como referência várias obras deste último, mas sobretudo são as ideias difundidas no contexto do movimento do Sturm und Drang, contra ou a favor da corrente dos "entusiastas", da Schwärmarei, que estão em causa. No contexto do Sturm und Drang surgiram muitas concepções sobre a imaginação, ímpeto e arte, as paixões da alma e o génio artístico, o lugar do entusiasmo na vivência religiosa, os limites do entusiasmo na vida política, etc., que motivaram a atenção de todos os intelectuais coevos, incluindo naturalmente Kant.

Kant reage ao espírito exaltado dos Schwärmer em vários escritos, desde logo na Crítica da Razão Prática tendo em conta a necessidade de respeitar os limites da razão e ainda num texto de 1790 Über Schwärmerei und die Mittel dagegen. Aqui, o excesso de "entusiasmo" é equiparado a uma "doença do espírito" e a censura aos entusiastas baseia-se na convicção de que para estes a experiência consistia essencialmente na apreensão da totalidade do objecto segundo a imaginação. A fantasia pode tornar-se, deste modo, na mais autêntica fonte de metafísica.

Mas com Kant e a sua análise da relação entre génio, gosto e universalidade do juízo estético entramos num domínio semântico que não tem as mesmas características dos textos analisados até aqui, com excepção parcial do Problema XXX. Trata-se de um âmbito especificamente filosófico em que o alcance semântico da terminologia está dependente da vigilância conceptual e de limites sistemáticos. A elasticidade semântica dos termos não é a mesma.

Para além da sua crítica às Ideias sobre a História Universal de Herder Kant reavalia criticamente os pressupostos da visão orgânica do mundo de inspiração leibniziana em várias ocasiões e as conexões sistemáticas entre as duas partes da Crítica da Faculdade de Julgar (a faculdade de julgar estética e a teleológica) não se pode considerar alheia à discussão com Herder ${ }^{81}$. Um dos temas associados a esse arrumo é o da origem da ideia de perfeição, que o autor de Gott havia concebido à luz de uma combinação eclética de wolffianismo e espinosismo. Na terceira Crítica a solução do problema do fundamento de um "critério universal" do gosto está intimamente relacionado com a rejeição do postulado objectivo da concordância entre percepção, juízo de gosto e antecipação da perfeição

${ }^{81}$ Cf. J. H. Zammito, The Genesis of Kant's Critique of Judgment, Chicago, 1992, pp. 185 e ss. 
nos objectos naturais. Muito embora o exame da teleologia esteja na segunda parte da Crítica, ele é um importante pressuposto das ideias sobre o juízo estético. A impossibilidade de garantir às representações teleológicas (e orgânicas) sobre o mundo um fundamento constitutivo para o juízo em sentido lógico assim como em sentido estético faz com que Kant coloque a faculdade de jugar e a universalidade dos seus princípios de fora do alcance das disputas sobre o plano imanente da natureza, não podendo obviamente fundar aquelas neste. Mas isto implica que também o gosto e o génio não se devam articular com as ideias (metafísicas) sobre a finalidade da natureza, a perfeição ou a continuidade da alma, como sede da faculdade de julgar, com elementos da composição natural dos objectos. Da crítica kantiana à cognoscibilidade dos objectos das Metafísicas Especiais faz parte a crítica ao postulado de uma comunidade entre natureza e espírito humano ou entre Mundo e Alma, em que se haviam baseado as concepções sobre a melancolia.

Relativamente ao gosto, na Analítica do Belo, a Crítica da Faculdade de Julgar defende uma estratégia no sentido de resolver o problema da particularidade subjectiva do prazer e a necessidade de presumir um critério universal de gosto mostrando como a consideração formal, a priori, do juízo de gosto não parte do que é privado e subjectivo na sensação, mas sim do puro valor cognitivo da forma da representação em geral. O "estado de espírito" que associamos ao gosto e que pode ser comunicado universalmente não é aquele que depende desta experiência subjectiva da contemplação deste objecto, mas o "livre jogo das faculdades" que tem necessariamente de acompanhar qualquer representação e que é fundamento do prazer estético. Ora, esta estratégia opõe-se à admissão prévia de princípios que subordinem a actividade psíquica a elementos da natureza (humores) ou a um arranjo determinado desses elementos. A comunicabilidade da universalidade das condições do juízo de gosto é a comunicabilidade de uma forma e não de um sentimento real vivido como tal numa comunidade definida, como a nação. Esta viragem kantiana para a universalidade da forma acaba por retirar todo o interesse à pesquisa do nexo real entre partes e todo de uma totalidade quer se trate de uma totalidade natural ou de uma comunidade de homens, pesquisa essa que teria sempre de ser metafísica. Conhecemos bem a argumentação kantiana a partir deste momento: a universalidade do juízo de gosto está garantida sem recurso a conceitos; é uma "universalidade sem conceitos"; na medida em que o "livre jogo das faculdades" representa uma dada maneira de observar a possibilidade de o espírito representar objectos não está, contudo, relacionado com a representação da natureza como um sistema de fins mas prende-se apenas com a conexão interna das faculdades ou a relação das faculdades representativas entre elas, 
como uma "finalidade sem fim". Em consequência vem a famosa nota do "desinteresse", segundo a qual o gosto é definido como a capacidade de associar uma representação ao sentimento subjectivo de satisfação por meio da faculdade de julgar e da imaginação, independentemente daquilo que por meio da vontade eu possa ligar do objecto, como objecto real, aos meus próprios fins práticos.

Ao partir da definição de génio como "disposição inata do espírito pela qual a natureza dá regras à arte", Kant era levado à noção de que as "belas-artes" se tinham de conceber como artes do génio ${ }^{82}$ (§ 46). Os argumentos do § 46 da Crítica da Faculdade de Julgar são determinantes para se compreender a tese kantiana e vão no sentido de uma concepção da individualidade criadora do génio que prescinde de modelos na natureza e, pelo contrário, se toma a si mesma como modelo. Esta concepção kantiana diverge no essencial das concepções tradicionais da criação artística mimética. A tese é proposta em quatro partes e começa desde uma hipótese. A hipótese diz que os produtos das "belas-artes" não se podem considerar como formados segundo regras ou segundo um conceito repetível. As "belas-artes" não podem explicar conceptualmente como é que os seus produtos foram concebidos. Resta atribuir ao "génio" segundo o livre jogo das suas faculdades a capacidade produtiva para as obras de arte.

É deste ponto de partida, que se justifica pela restante base axiomática desta Crítica, que se vão seguir as quatro consequências. A primeira diz que o génio é um talento determinado que consiste em ser capaz de produzir o que não sabemos explicar por nenhuma regra determinada e tem de se conceber, por conseguinte, como originalidade; os produtos do génio não são imitações mas são exemplares e prestam-se à imitação; o génio não pode explicar por nenhum meio objectivo o modo como produziu os seus produtos, pelo que ele terá de se referir a si próprio como única e exclusiva fonte dos produtos da sua arte e a relação entre os seus produtos e ele próprio é uma relação circular, concebida como uma "natureza" do próprio génio ou algo de "inato" na sua subjectividade; a "natureza" que supomos actuar através do génio produz os seus resultados nas "belas-artes" mas não na ciência. Esta última consequência do $\S 46$ é bem clara: Kant considera que o génio não tem qualquer aplicação na ciência. O filósofo confina a actuação do "modelo sem regra" à arte.

A concepção kantiana do génio é, portanto, restritiva. $O$ facto de não pode falar-se com propriedade de génio na ciência quer dizer que, aqui, a hipótese de um criador de regras do juízo não tem aplicação nem teria uma função clara. Assim, o génio entra na mesma categoria das ficções da

${ }^{82}$ I. Kant, Kritik der Urteilskraft, Leipzig, $1922^{5}$, p. 160. 
razão e do juízo que todas as demais que se haviam aceite para explicar o "livre jogo das faculdades" na geração do sentimento do agradável. Mas parece evidente que isto significa a rejeição de um realismo psicológico e social do génio.

\subsection{Hegel e o génio}

Na Estética, Hegel recebe e reconfigura a tradição do génio como fonte da obra de arte sem qualquer alusão às doutrinas humorais sobre o génio. $\mathrm{O}$ entusiasmo ou a inspiração estão presentes mas já sem a referência ao modelo antigo da natureza humana. Os aspectos da semântica do génio relacionados com a nação são especialmente reconfigurados e nisto a sua obra depende de algumas ideias de Herder sem se confundir com as suas teses metafísicas e pré-nacionalistas. As Lições sobre Estética partem da ideia de que a obra de arte possui um período de gestação intimamente associado à subjectividade criadora do artista. $\mathrm{O}$ que constitui o núcleo produtivo da subjectividade criadora encontra-se no génio e no Talento. Se o talento representa a faculdade que se pode aprender, ensinar e treinar, o génio coloca problemas e insere-se, como temos visto, numa linha de herança semântica mais rica. $O$ filósofo começa por notar a respeito do conceito de génio o seu carácter geral ou seja o facto de se aplicar em domínios que não se limitam ao da Arte. Um deles é o controverso domínio da Ciência.

No caso da Arte, o génio foi, na maior parte dos casos, associado à imaginação e à fantasia. $\mathrm{Na}$ análise da fantasia como poder criador o filósofo começa por separar esta faculdade da imaginação passiva, cuja característica é a de combinar dados que já estão na posse de outra faculdade do espírito, sem variação significativa. A fantasia que importa reter para compreender o papel da imaginação na arte é o tipo da imaginação produtora e activa ${ }^{83}$. As Lições sobre Estética retomam a longa tradição das teorias da imaginação como fonte do novo no espírito. Da produtividade própria da fantasia faz parte um "dom" que se relaciona com uma determinada capacidade de percepcionar o mundo. $\mathrm{O}$ texto refere ao mesmo tempo uma Auffassen e uma Gedächtnis. Na sua descrição não há nenhuma fonte orgânica e tudo se passa no terreno da actividade cognitiva da mente. A apreensão está relacionada com um "ouvir" e um "ver" atentos. O objecto da atenção-que-apreende está na realidade, mas

${ }^{83}$ G. W. F. Hegel, Vorlesungen über die Ästhetik I, in Idem, Werke 13 (E. Moldenhauer / K. M. Michel, Hrsg.), Frankfurt / M., 1986, p. 363. Vou centrar-me apenas na divisão “C. Der Künstler”, do terceiro capítulo da primeira parte. 
na medida em que esta se dá em determinações e perspectivas concretas. A memória conserva a múltipla aparência sensível.

A fantasia do génio não está em obediência a construções do entendimento mas está concentrada na multiplicidade das partes de uma unidade vital. Ora, é nisto que a Arte se deve afastar da Filosofia, pois esta última parte directamente do elemento do pensamento.

$\mathrm{Na}$ composição artística da obra de arte, o que representa a fonte próxima da unidade vital é o próprio artista como centro de uma biografia. Aqui, ele deve sentir-se como "em casa" (heimisch) no elemento em que se vem exprimir a multiplicidade e variedade da experiência pessoal da sua vida. Esta proximidade ao múltiplo e ao variado da experiência não tem as características do pensamento filosófico ou de uma forma do pensamento abstracto. O exemplo é Goethe que, ao longo de toda a sua vida, não terá feito outra coisa a não ser alargar o alcance da sua intuição penetrando cada vez mais dentro de si. Este alargamento da intuição de tal modo que daí resulta uma aprendizagem vital que coincide com o ser pessoal é um dom típico da personalidade genial. A intuição refere-se sempre à realidade exterior mas também à vida interior e aos sentimentos do artista. Um nexo muito cerrado entre exterioridade e interioridade produz-se então.

$\mathrm{Na}$ apreensão da realidade exterior não conta apenas aquilo que pertence à aparência exterior fenomenal, que é largamente contingente. $\mathrm{Na}$ medida em que a obra de arte representa a Ideia como Ideal ela apreende também as modalidades que estão na base dessa efectivação do ideal no real. Neste sentido, a obra de arte mediante a representação do artista está voltada para este "ideal no real" a que o filósofo chama "racionalidade". É de afastar, por isso, a ideia de que o artista é um indivíduo dotado de uma especial inspiração misteriosa. Põe-se de lado, portanto, as explicações com base no furor divino. Os elementos psicológicos que se podem reter, mas que alcançam um significado mais vasto que a idiossincrasia, são o da grande concentração de espírito e o poder de diferenciação e exame. A elevada concentração de espírito permite ao artista de génio organizar os materiais da sua experiência de acordo com as finalidades da obra de arte. Mas a reunião das condições subjectivas para a orientação do espírito para a obra implica uma transformação interior profunda e a reorganização da vida subjectiva enquanto tal. O material disponível na experiência tem de ser de tal forma organizado e orientado que todo ele tem de começar a fazer parte do núcleo mais essencial do "si mesmo" do sujeito, como se se tratasse da sua "propriedade interior": hat der Künstler seinen Stoff und dessen Gestaltung als sein eigenstes Selbst, als innerstes Eigentum seiner als Subjekt ${ }^{84}$.

${ }^{84}$ Idem, Ibid., p. 366. 
A transformação da vida do artista é essencial para que ele possa então iniciar o processo de criação artística. É neste sentido que a consciência de uma determinada unidade autobiográfica é essencial para que a obra de arte adquira profundidade. Esta está então relacionada com a capacidade que tem o artista de dar uma direcção e um sentido à sua própria experiência de si na relação com a sua experiência de mundo. É com isto que Hegel associa também a maturidade do artista e da obra. É-lhe possível então chegar à definição do talento e do génio no seio de uma relação que envolve a subjectividade do artista, as suas faculdades assim como a sua experiência pessoal do mundo: Diese produktive Tätigkeit nun der Phantasie, durch welche der Künstler das an und für sich Vernünftige in sich selbst als sein eigenstes Werk zur realen Gestalt herausarbeitet, ist es, die Genie, Talent, usf. genannt wird ${ }^{85}$.

A diferença entre génio e talento supõe uma determinada diferenciação interna de disposições subjectivas e de habilidades práticas mas requer não só a presença do génio como ainda as operações que conduzem à composição artística. Nesta acepção, especialmente operatória, o génio é um centro organizador da energia do espírito subjectivo e da sua concentração numa actividade definida.

Sobre o tema da origem inata do génio as Lições sobre Estética escolhem uma via conciliadora ao afirmarem que a ideia não é totalmente verdadeira nem totalmente falsa. Na medida em que a criação artística tem de partir de um elemento natural e imediato isso vai implicar que o artista labore já a partir de qualquer coisa dado. É este dado que se chamou o elemento inato do génio, mas com impropriedade. $\mathrm{O}$ chamado carácter nacional das nações e dos povos faz também parte deste dado, que é incorporado igualmente na obra. De acordo com este dado nacional certos povos estariam vocacionados, pela natureza, para a prática de certas actividades artísticas distinguindo-se nisso de outros povos. A partir do dado interno e externo o artista tem ainda de orientar a sua actividade pelas exigências peculiares do tipo de arte a que se dedica. Esta capacidade num elevado grau que se identifica com uma prática "sem esforço" é, segundo o filósofo, o efeito de uma natürliche Trieb. O impulso natural para reunir sob a sua actividade criadora os dados de que dispõe mas num domínio artístico limitado, segundo um Ideal, define o génio.

É a respeito dos dados naturais de que parte o artista para a composição que nas Lições sobre Estética são referidos os temas do entusiasmo (Begeisterung) e da inspiração. Assuntos como o uso de drogas ou a orientação da inspiração pela vontade ou por estímulos externos são tidos como menos sérios. O decisivo está na capacidade do artista

85 Idem, Ibid., idem. 
para fazer coincidir o objecto da composição consigo, com a sua vida. É desta identidade entre o objecto da obra e o sentido de uma biografia que pode nascer a inspiração no sentido subjectivo do termo. Em que consiste então a inspiração? A resposta vai no sentido do conceito dialéctico de coisa (Sache): (...) so ist sie nichts anders (a inspiração) als von der Sache ganz erfüllt zu werden, ganz in der Sache gegenwärtig zu sein ${ }^{86}$. Em vez de vigorar a subjectividade do criador, para haver inspiração tem de vigorar a própria coisa. $\mathrm{O}$ inspirado não é o exaltado. $\mathrm{O}$ criador tem de descer até à própria coisa do seu afazer, confundir-se com ela, deixar absorver-se por ela, ganz in den Stoff versenken ${ }^{87}$. Há um bom e um mau entusiasmo, pois há um entusiasmo que provém da identidade vital entre a coisa e a sua forma subjectiva e um entusiasmo da fantasia arbitrária. Vemos, portanto, como Hegel tenta a solução das tensões da semântica do entusiasmo à luz da articulação entre o interior e o exterior ou o subjectivo e o objectivo. A relação entre os elementos subjectivo e o objectivo no caso da inspiração depende da clarificação de duas noções: a de manifestação e a de expressão.

Ambas as ideias confluem no conceito de obra de arte. Só na obra encontramos o artista e não na interioridade entusiástica do inexprimível. Deste inexprimível não há qualquer noção apropriada. Por conseguinte, é na objectividade da obra de arte que podemos avaliar a qualidade da inspiração artística e, sobretudo, a sua fidelidade ao que está em causa. As Lições sobre Estética referem a propósito uma Kunstverkörperung. À identidade sujeito-objecto na Kunstverkörperung chama Hegel a verdadeira originalidade ${ }^{88}$. Esta última diferencia-se então da Manier, que apenas assenta nas particularidades subjectivas isoladas ou artificialmente produzidas e que nada tem de aproximável ao Ideal que pede para se exprimir na obra. Ora, neste conceito da objectividade da obra de arte está incluída a noção de público e de um ser-para-nós da obra, mais uma vez na proximidade da nação.

Com as Lições de Hegel estamos num período de desenvolvimento da cultura do génio e da concepção da sua individuação que está longe das teses metafísicas sobre a unidade teo-psíco-somática da personalidade de excepção. A crise do modelo expressivo da metafísica do génio abriu-se antes de Hegel, com Kant, na crítica dos pressupostos das teses de Herder. E estas últimas haviam levado a semântica clássica do génio a um ponto que impunha uma viragem. Refiro-me à tentativa de incluir a comunicação em sociedade no conjunto dos factores do Uno-Todo que contribuíam para

\footnotetext{
${ }^{86}$ Idem, Ibid., p. 373.

${ }^{87}$ Idem, Ibid., idem.

${ }^{88}$ Idem, Ibid., p. 376.
} 
a individuação do génio. Dentro da sua nação e como expressão pátria o génio surgia-nos como um medium da alma colectiva e o entusiasmo tornava-se, então, uma corrente colectiva estética. Mas o problema que aguardava esta construção era o da impossibilidade de perseguir a ideia de sociedade a partir de uma mesma unidade de sentimento. A formalização kantiana da Estética e do conceito de génio dão provas das fraquezas e dos impasses de Herder e do conceito sensualista do juízo de gosto a respeito da noção de universalidade do juízo estético, de um só fôlego. A Crítica da Faculdade de Julgar mostrou como a universalidade do gosto não pode assentar na pressuposição de um acordo ou participação num sentimento universal comum, de algum modo sempre latente, mas representa uma condição formal que por isso mesmo está aberta à contingência empírica, mas sem a definir à partida nas suas qualidades e predicados. É evidente que quando Hegel transforma o tema do génio no problema das condições de produção do Ideal na arte a partir da força e capacidade de intuição do objecto da obra e quando identifica a nação com o público da arte está a dissolver, na prática, também, a fonte metafísica do princípio psico-somático do génio e a base sentimental, na alma colectiva, que unia o artista à corrente espiritual da comunidade como uma só pulsação. Ambos, Kant e Hegel, reflectem na época da crise do génio o fim de um modelo de "natureza humana" e da correspondente individuação.

\section{REFERÊNCIAS SUMÁRIAS}

WILLIAM BELSHAM, "Observations on Genius" in Idem, Essays, Philosophical, Historical, Literary, "Essay XX”, London, 1789.

HUGH BLAIR, A Critical Dissertation on the Poems of Ossian, the Son of Fingal, London, 1763.

R. BRANDT, Kritischer Kommentar zu Kants Anthropologie in pragmatischer Hinsicht (1798), Hamburg, 1999.

N. L. BRANN, The Debate over the Origin of Genius during the Italian Renaissance, Leiden, Boston, Köln, 2001.

T. BRIGHT, A Treatise of Melancholie. Containing the Causes thereof with the phisicke Cure, and spirituall Consolation, London, 1586.

E. BURKE, A Philosophical Enquiry into the Origin of our Ideas of the Sublime and Beautiful, with an introductory Discourse concerning Taste, London, 1767.

R. BURTON, DEMOCRITUS JUNIOR, The Anatomy of Melancoly, Oxford, 1638 , the fifth edition corrected and augmented by the author. 
F. A. CARUS, Psychologie in Idem, Nachgelassene Werke, Erste Teil, Leipzig, 1808.

MÉRIC CASAUBON, A Treatise concerning Enthusiasme as it is an effect of Nature, London, 1655.

R. DAVAL, Mélancolie, Ivresse et Enthousiasme, Paris, 2009.

M. FICINO, Liber de Vita in tres libros divisus / Buch vom Leben in drei Teilbüchern (trad. alemã R. Hirth), 2007: pascua.de/ficinus.

D. C. FOUKE, The Enthusiastical Concerns of Dr. Henry More: Religious Meaning and the Psychology of Delusion, Leiden, New York, Köln, 1996.

A. GERARD, An Essay on Genius, London, 1774.

G. W. F. HEGEL, Vorlesungen über die Ästhetik I, in Idem, Werke 13 (E. Moldenhauer / K. M. Michel, Hrsg.), Frankfurt / M., 1986.

F. HEMSTERHUIS, Lettre sur l' Homme et ses Rapports, Paris, 1772.

J. G. HERDER, Sämmtliche Werke, Bd. 1 Zur Schöne Literatur und Kunst, Carlsruhe, 1821.

Idem, Stimmen der Völker in Lieder, Wien, 1813.

Idem, Gott. Einige Gespräche über Spinoza's System, nebst Shaftesburi's Naturhymnus, Gotha, 1800.

Idem, Briefe zu Beförderung der Humanität, Riga, 1793.

R. HORLACHER, Bildungstheorie vor der Bildungstheorie: die Shaftesbury-Rezeption in Deutschland und der Schweiz im 18. Jahrhundert, Würzburg, 2004.

I. KANT, Kritik der Urteilskraft, Leipzig, 1922.

R. KLIBANSKY, E. PANOFSKY, F. SAXL, Saturne et la Mélancolie. Études Historiques et Philosophiques: Nature, Religion, Médicine er Art (trad.), Paris, 1989

A. DU LAURENS, Discours de la Conservation de la Veue, des Maladies Mélancholiques, des Catarrhes, et de la Vieillesse, Paris, 1597.

J. LOCKE, An essay concerning human understanding, with Thoughts on the conduct of the Understanding in three volumes, vol. III, Edinburgh, 1801.

C. LOMBRoso, L' Homme de Génie, (trad.), Paris, 1889.

J. MACPHERSON, The poems of Ossian translated by James Macpherson in two volumes, London, 1790.

MONTESQUIEU, Essai sur le Goût in Idem, Euvres Complètes, Paris, 1964.

H. MORE, Enthusiasmus Triumphatus, or a Brief Discourse of the Nature, Causes, Kinds, and Cure of Enthusiasm in Idem, A Collection of several Philosophical Writings of Dr. Henry More, London, 1712.

A. RAMSAY, A Dialogue on Taste, London, 1762 (the second edition). 
SHAFTESBURY, A Letter concerning Enthusiasm, London, 1708.

F. CARTAUD DE LA VILLATE, Essai Historique et Philosophique sur le Goust, Amesterdam, 1736.

VOlTAIRE, Le Temple du Goût. Édition Véritable donnée par l'Auteur, Amsterdam, 1733.

J. H. ZAMMITO, The Genesis of Kant's Critique of Judgment, Chicago, 1992. 